\title{
CAMA
}

Centre for Applied Macroeconomic Analysis

\section{Dutch disease, real effective exchange rate misalignments and their effect on GDP growth in the EU}

\section{CAMA Working Paper 28/2016 May 2016}

\section{Mariarosaria Comunale}

Applied Macroeconomic Research Division, Economics Department, Bank of Lithuania and

Centre for Applied Macroeconomic Analysis, ANU

\begin{abstract}
In this article we study the impact of real effective exchange rate misalignments, based on determinants, including different types of foreign capital inflows, on GDP growth in the EU. This can provide a useful contribution to understanding the causal link between inflows, real effective exchange rate disequilibria and GDP growth during both the boom and the crisis period. For this analysis, we use a panel of $27 \mathrm{EU}$ countries for the period 1994-2012, with annual frequency.

We find that the core countries have been mostly undervalued from the crisis onwards, while the periphery (excluding Ireland) were overvalued starting from 2003-2004, as expected. Concerning the new Member States, these are persistently overvalued for the entire time span. The results seem to be generally driven by the inflows of banking loans more than by FDIs or portfolio investments.

In the second stage, we study the influence of exchange rate misalignments and volatilities on growth. We argue that the real effective exchange rate misalignments associated with the inflows have been a further cause for decline in GDP, in a long-run perspective, while they do not play a role in the short run. The exchange rate volatilities and the undervaluation dummy are not robust in affecting GDP growth, while spillovers and global factors seem to matter in all the specifications both in the short and long run.
\end{abstract}




\section{Keywords}

real effective exchange rate, behavioural effective exchange rate, foreign capital inflows, FDIs, Dutch disease, GDP growth, European Union

\section{JEL Classification}

$\mathrm{F} 31, \mathrm{~F} 43, \mathrm{C} 23$

\section{Address for correspondence:}

(E) cama.admin@anu.edu.au

\section{ISSN 2206-0332}

The Centre for Applied Macroeconomic Analysis in the Crawford School of Public Policy has been established to build strong links between professional macroeconomists. It provides a forum for quality macroeconomic research and discussion of policy issues between academia, government and the private sector.

The Crawford School of Public Policy is the Australian National University's public policy school, serving and influencing Australia, Asia and the Pacific through advanced policy research, graduate and executive education, and policy impact. 


\title{
DUTCH DISEASE, REAL EFFECTIVE EXCHANGE RATE MISALIGNMENTS AND THEIR EFFECT ON GDP GROWTH IN THE EU
}

\author{
Mariarosaria Comunale ${ }^{1}$
}

May 2016

\begin{abstract}
In this article we study the impact of real effective exchange rate misalignments, based on determinants, including different types of foreign capital inflows, on GDP growth in the EU. This can provide a useful contribution to understanding the causal link between inflows, real effective exchange rate disequilibria and GDP growth during both the boom and the crisis period. For this analysis, we use a panel of 27 EU countries for the period 1994-2012, with annual frequency.

We find that the core countries have been mostly undervalued from the crisis onwards, while the periphery (excluding Ireland) were overvalued starting from 2003-2004, as expected. Concerning the new Member States, these are persistently overvalued for the entire time span. The results seem to be generally driven by the inflows of banking loans more than by FDIs or portfolio investments.

In the second stage, we study the influence of exchange rate misalignments and volatilities on growth. We argue that the real effective exchange rate misalignments associated with the inflows have been a further cause for decline in GDP, in a long-run perspective, while they do not play a role in the short run. The exchange rate volatilities and the undervaluation dummy are not robust in affecting GDP growth, while spillovers and global factors seem to matter in all the specifications both in the short and long run.
\end{abstract}

Keywords: real effective exchange rate, behavioural effective exchange rate, foreign capital inflows, FDIs, Dutch disease, GDP growth, European Union.

JEL Classification: F31, F43, C23

\footnotetext{
${ }^{1}$ Principal Economist, Applied Macroeconomic Research Division, Economics Department, Bank of Lithuania, Totoriu g. 4, LT01121 Vilnius (Lithuania). E-mail: mcomunale@lb.lt; mariarosaria.comunale@ gmail.com; tel. +370 52680103. Research Associate Centre for Applied Macroeconomic Analysis, The Australian National University, Canberra.

I am very thankful to Mihnea Constantinescu (Bank of Lithuania), Povilas Lastauskas (University of Cambridge), Camelia Turcu (Université d'Orléans), Yannick Lucotte (Paris School of Business) and an anonymous referee for the useful comments and suggestions. I would also like to thank the participants and lecturers of the course "Macroeconomic Policies in Times of High Capital Mobility" at the Joint Vienna Institute (JVI) in Vienna, the participants of the internal seminar at the Bank of Lithuania and at the ECB, of the INFER Workshop on "European Integration in the Aftermath of Debt Crisis" in Bratislava and of the research seminar at Paris School of Business for their comments and useful feedback. I acknowledge the useful help by Karina Majevskaja (Vilnius University) in updating the weights for the relative measures and Julius Stakenas (Bank of Lithuania) for the idea of a GVAR way to reduce cross-sectional dependence. I thank Raimondas Kuodis (Bank of Lithuania) for the discussion on banking flows and Silvia Calò (European University Institute) for the discussion about the impact of government expenditure on growth.
}

The conclusions expressed in the paper are those of the author and do not necessarily represent the official views of the Bank of Lithuania. 


\section{Introduction}

In this paper we study the impact of real effective exchange rate (REER) misalignments, based on REER determinants, including foreign capital inflows, on GDP growth in the EU. It also looks at the so-called "Dutch Disease" phenomenon, which reflects changes, caused by a favourable shock, in the structure of production. The changes in production can influence both competitiveness and growth. Examples of cases of Dutch Disease are, among others, the discovery of a large natural resource, a rise in the international price of an exportable commodity, the presence of sustained aid or, indeed, huge foreign capital inflows (Brahmbhatt et al., 2010). Most of the literature on Dutch Disease has stressed the impact of inflows on the real effective exchange rate (REER), but to the best of our knowledge, an analysis of this kind for the EU, in light of the recent decade, linking the REER misalignments and growth to the boom in foreign capital inflows, has not been considered before. This can give a useful contribution in understanding the causal link between inflows, REER disequilibria and GDP growth in the context of the EU (and the euro area) during the boom and the following crisis period.

Firstly, we calculate the misalignments starting from the behavioural effective exchange rate (BEER) as the equilibrium value and applying the same setup developed in Comunale (2015 a, b). The determinants of REER (CPI deflated) include: different foreign capital inflows as in Combes et al. (2012) and Corden (1994); terms of trade and a proxy for the Balassa-Samuelson effect, i.e. the real GDP per capita relative to the partners. This is an alternative approach compared to the "transfer problem" theory (Lane \& Milesi-Ferretti, 2002 and 2004; Vieira \& MacDonald, 2012). The coefficients are estimated by Group-Mean Fully modified OLS (GM-FMOLS) estimator (Pedroni, 2000). The equilibrium value is then built by the coefficients multiplied by the HP-filtered value of the explanatory variables. ${ }^{2}$ The misalignment is the difference between the actual REER and the calculated equilibrium value (BEER). In this way we also highlight the impact of inflows on the REER, which is one of the main outcomes coming from the Dutch Disease literature.

We emphasise here the role of a huge increase in capital inflows in determining the REER misalignments and, after that, we study their influence on growth. We use a panel of 27 EU countries for the period 1994-2012, with annual frequency. As for this paper, we estimate the GDP growth in a dynamic panel setup by using the REER misalignments along with government expenditure. Government expenditure is an important factor for GDP growth in the long-run across EU countries (Arpaia \& Turrini, 2008) ${ }^{3}$ and it has been included in several

\footnotetext{
${ }^{2}$ As reported by Schnatz (2011) and Clark \& MacDonald (1999, 2004), HP filtering of the fundamentals takes into account the possible misalignments of these variables themselves, giving only their permanent part. This methodology (BEER) differs from the alternative (Permanent Equilibrium Exchange Rates, PEER) by the methodology used to calculate the permanent component of the determinants. The BEER uses the HP filtering technique; while the PEER is built by performing a permanent-transitory decomposition as suggested by Gonzalo \& Granger (1995). We decided to use the BEER as a measure of the "equilibrium" REER as a benchmark to judge the actual rate, because it has been proven as being more reliable in the case of small samples (Schnatz, 2011) and in order to better compare our results with the literature based on IMF CGER.

${ }^{3}$ In fact, government expenditure and potential output in the EU are linked by a stable long-run relation, as argued by Arpaia \& Turrini (2008).
} 
analyses of GDP growth determinants (Rodrick, 2008). The direction of this link, however, is still under analysis by both the theoretical and empirical literature on growth. ${ }^{4}$ Furthermore, we take into account also the role of global factors and spillovers among EU members. It is worth noting that the overvaluations may also have a different impact on growth compared to undervaluation cases. In this case we analyse the whole panel in an alternative setup by introducing a dummy for the cases of real undervaluation, in the spirit of Berg \& Miao (2010).

Lastly, we include in the last specification the volatility in the REER or in the nominal effective exchange rate (NEER), which can also influence the coefficient of the misalignments as suggested by Eichengreen (2008) and Boar (2010). Exchange rate volatility can indeed discourage trade and investment, which are important for growth. As in Calderon (2004), the more flexible the exchange rate regime is (and the more independent your monetary policy is), the more volatile are the fluctuations. In addition, the volatility of transition countries with flexible regimes is higher than developed countries with floating exchange rates.

However, in this analysis there is an evident identification problem, because the determinants of REER, from which the misalignments are generated, are partially also determinants of GDP growth itself, as highlighted in Berg \& Miao (2010) and Rodrik (2008) and reported in Magud \& Sosa (2010). As for this paper, we estimate the GDP growth in a dynamic panel setup by using the REER misalignments only along the government expenditure, as also applied in Vieira \& MacDonald (2012) $)^{5}$, and the undervaluation dummy. We do not include regressors already into the REER determinants equation. In our setup, the role of convergence, normally incorporated in an initial income ${ }^{6}$ variable is played by the relative GDP per capita into the REER equation and captured also by the lagged value of the GDP growth itself. ${ }^{7}$

The main point is indeed whether a massive change in REER, due to capital inflows, leads to a new long-run equilibrium or if it is just an overshoot leading to misalignments from the actual equilibrium based on fundamentals. To make this distinction, we need first of all to distinguish among the different types of inflows. FDIs are normally associated with investments in a longer time perspective, while portfolio investments should be more related to short-term movements. Hence, FDIs should have a positive effect on price competitiveness if directed to tradable/productive sectors (with negative coefficients for REER) or the other way around if they have been used to increase non-tradable sectors of the economy. Portfolio investments and other (mainly banking loans) are normally associated with investment in non-tradables and

\footnotetext{
${ }^{4}$ Among other contributions: Blanchard \& Perotti (2002) and Auerbach \& Gorodnichenko (2012) find an important but asymmetric effect of government expenditure on GDP.

${ }^{5}$ They used a system GMM estimator with time dummies (xtabond 2 command in Stata- Blundell-Bond setup).

${ }^{6}$ The role of initial income is explained in the neo-classical growth model (Barro, 1991). Here it is seen as proxies for convergence in the EU.

${ }^{7}$ The results, including GDP per capita, in our setup are available upon request. This variable is positive and significant only in the short run in all the specifications.
} 
constructions and are expected to influence negatively the competitiveness (i.e. they increase the REER). In the European case we saw in the period before the crisis a huge increase in short-term investments leading a boom in countries of the so-called periphery (Spain, Greece) and CEECs (Baltics) which have been directed to non-productive sectors of the economy such as construction and real estate. Have these massive inflows influenced the long-term growth of these countries? Were the REER misalignments associated with the inflows a further cause of declining in GDP (as well as of other components) in the bust phase? We expect to have an inverse relation between REER misalignments (calculated as actual value of REER minus the equilibrium, where a negative misalignment stands for an undervaluation) and GDP growth, with higher coefficients for new Member States (as for developing countries in Vieira \& MacDonald, 2012).

We find that the core countries have been mostly undervalued from the crisis onwards, while periphery were overvalued starting from 2003-2004, as expected. However, Ireland has been constantly undervalued for the period considered and only in 2008-2009 slightly overvalued. Concerning the new Member States, these are persistently overvalued for the entire time span, which means that their REERs are higher than their equilibrium values, i.e. they are less competitive as they should be. The results seem to be generally driven by the inflows of banking loans more than by $\mathrm{FDIs}^{8}$ or portfolio investments. Moreover, we can say that the REER misalignments associated with the inflows have been a further cause of declining in GDP, in a long-run perspective, while they do not play a role in the short run. The volatilities in the exchange rates and the undervaluation dummy do not affect GDP growth, while spillovers and global factors seem to matter in all the specifications both in the short and long run.

The rest of the paper is structured along the following lines. Section 2 provides an overview of various aspects of the literature. Section 3 lays out the methodology to calculate equilibrium exchange rates, misalignments and volatilities. Section 4 provides information on the data sources and their description. Section 5 presents the diagnostics and the estimation strategies, while results and robustness checks are provided in Section 6. Section 7 concludes.

\section{Literature review}

There are three main relevant literature strands related to the current research question. The main one provides the measures of "equilibrium" REER. As explained in Maeso-Fernandez et al. (2002) there are many ways to calculate the equilibrium, among them we selected two methods also widely used by the IMF in the Consultative Group on Exchange Rate Issues (CGER). We present the resulting misalignments coming from

\footnotetext{
${ }^{8}$ An interesting case during the period of 1994-2012 can be found in the Czech Republic. In this case, the Czech National Bank (Česká národní banka) had to intervene against its currency in 2001-2002, because huge FDI inflows caused an unsustainable nominal overvaluation. However, the real misalignments were not problematic with respect to other countries or periods (i.e. around 0.20, see Fig. 3). This is because FDIs are generally directed towards more productive sectors and this can impact the REER via the embedded prices, smoothing the reaction of a country to nominal overvaluation.
} 
the so-called BEER method. The BEER has been studied in Clark \& MacDonald (1999) and Bénassy-Quéré et al. $(2009,2010)$ among others. In this method the importance of the determinants of REER are recognised and they are used to calculate the "equilibrium value".

Another strand of literature involved in our analysis refers to the Dutch Disease phenomenon. As explained in Magud \& Sosa (2010), most of the Dutch Disease literature stresses the impact of inflows on REER, but there is a lack of consensus on the link between the misalignments and long-term growth and there still are not many papers that analyse this phenomenon. The initial beneficial effect of inflows can indeed be offset by the decline in the production and export of mostly manufacturing, traded goods due to an excessive appreciation of the REER. The REER itself can go up due to a sudden increase in demand for non-tradable goods and services. The Dutch Disease may also be amplified by increasing volatility of the REER, which lowers the investment volumes in tradables even more (Gylfason et al., 1999). In the literature there is a first strand of papers, which focus on the impact of remittances and aid flows and show evidence of the Dutch Disease. For instance, in Lartey et al. (2008), the authors find stronger evidence in the fixed effect regimes, where an increase in remittances leads to REER appreciation and a decline of the ratio of tradable over non-tradable output. Also, in this case there is a lack of consensus in the literature. Rajan \& Subramanian (2005) do not find a Dutch Disease effect due to an increase in remittances. In the same article, the authors find evidence suggesting that foreign aid does instead create a Dutch Disease phenomenon. It is good to recall that other studies show, however, that the Dutch Disease is not a straightforward effect of aid flows (IMF, 2005).

On the other side, the literature about the influence of REER on GDP growth is quite extensive. The oldest studies confirm the negative influence of REER instability or distortion on growth (Dollar, 1992, for instance, analysing the 1970s and 80s). Aguirre \& Calderon (2005) show that misalignments in the REER even help predict GDP growth in a sample of developed and emerging countries. In the more recent export-led growth literature instead, an undervalued exchange rate is proved, having a positive effect on growth, while overvaluation is linked with low growth episodes as in Rodrik (2008). ${ }^{9}$ However, as stressed in Berg \& Miao (2010), the REER is not a policy instrument but a result of policy actions and externalities and, in any case, an undervalued REER could bring a "beggar-my-neighbour" effect. On the opposite side of the debate, the socalled Washington Consensus ${ }^{10}$ view considers both types of REER misalignments bad for growth in a longterm perspective.

In addition, an analysis of the link between REER misalignments and long-term growth has been provided by Gala \& Lucinda (2006) and Vieira \& MacDonald (2012), by using panel data setups. Results of Gala \& Lucinda (2006) indicate that a real depreciation, i.e. increase in competitiveness, is associated with higher

\footnotetext{
${ }^{9}$ However, Rodrik (2008) defines a measure of undervaluation as a deviation of the actual real exchange rate from its purchasingpower-party (PPP) value, adjusted for the effects of per capita income on the real exchange rate. A simple model of RER and growth is also described there. Rodrik (2008) estimates the results for a panel of 184 countries in the period 1950-2004.

${ }^{10}$ The original Washington Consensus manifesto is in Williamson (1990).
} 
GDP growth. This paper studies the link between REER and growth by using a dynamic panel data analysis with GMM techniques, for 58 countries in 1960-1999. Vieira \& MacDonald (2012) also find a positive coefficient for the REER misalignments ${ }^{11}$ (calculated in different ways) for a panel of 80 countries from 1980 to 2004. The estimated coefficients with a system-GMM are higher for developing countries. More recently, an approach similar to ours has been applied in Owoundi (2016) addressing the issue of the growth effects of currency misalignments in the Sub-Saharan African countries of the Franc Zone area. The author uses the socalled BEER method as well and controls for cross-sectional dependence. They demonstrate that deviations of the REER from its equilibrium level do not exercise a favorable effect on growth for the countries considered, whether the currency is overvalued or undervalued.

Lastly, Eichengreen (2008) studies the channel through which the REER misalignments and exchange rate volatility can influence GDP growth in the long-run. The author supports the results in Rodrik (2008) but also highlights that a depreciated REER does not have to be associated with high exchange rate volatility to have a positive influence on long-term growth. The volatility here is meant as the nominal exchange rate volatility. In any case, this is associated with greater volatility of the real exchange rate as explained in Mussa (1986). However, in this regard, Boar (2010) stresses that the intensity of the link is higher in the case of REER volatility rather than for NEER.

\section{Empirical framework}

Concerning the empirical methodology, we firstly estimate the coefficients concerning the fundamentals of the REER, namely: the foreign net capital inflows (flows divided into FDIs, portfolio investments and other investments), the terms of trade as exports unit value over imports unit value (tot) and the Balassa-Samuelson effect represented by the real GDP per capita relative to the partners $(b s) .{ }^{12}$ The theoretical background of this setup can be found in Lane \& Milesi-Ferretti (2004) and in Corden (1994). The log-linearised model resulting from the analysis is, therefore, the following:

$\operatorname{reer}_{i, t}=\alpha_{i}+\beta_{i}{ }^{\prime} X_{i, t}+\varepsilon_{i, t}=f\left(\right.$ flows $_{i, t} ;$ tot $\left._{i, t} ; b s_{i, t}\right)$

where reer is the $(\log )$ of REER and $\mathrm{X}$ are the determinants. We use the REER deflated by Consumer Price Index (CPI) vis-à-vis the main partners. The equilibrium rate is calculated as the estimated coefficients from

\footnotetext{
${ }^{11}$ This means that more depreciated REER helps growth in the long-run, because here the REER misalignments are calculated as the equilibrium value minus the actual REER.

${ }^{12}$ For an analysis on the impact of different proxies for the Balassa-Samuelson effect, based on relative productivities, in EU 28, see Comunale (2015a). In this paper two alternative measures are considered in estimating the REER determinants: productivity in industry as a proxy for productivity in manufacturing (value added in constant 2005 USD over number of employees) relative to the weighted average of partners and the productivity in industry over productivity in services relative to weighted average of partners. The results are comparable with the ones with relative GDP per capita as a proxy for the Balassa-Samuelson effect.
} 
equation (1) times the HP filtered value of the fundamentals (Carrera \& Restout, 2011) ${ }^{13}$ So, for each country we compute the equilibrium REER $\overline{r e e r}_{i, t}$ as in equation (2). Therefore, we have a time-varying equilibrium for the REER.

$\overline{\operatorname{reer}}_{i, t}=\hat{\beta}_{i}^{\prime} X_{i, t}^{H P}$

Hence, the misalignments reer $_{i, t}^{\text {mis }}$ are computed as: $\operatorname{reer}_{i, t}^{\text {mis }}=$ reer $_{i, t}-\overline{r e e r}_{i, t}$. The index relative to these misalignments will be named $R E E R m i s_{i, t}$ in the further steps.

Then we calculate the volatilities ${ }^{14}$ from the monthly data for REER-CPI (equation (3)) and NEER (equation (4)) vis-à-vis 37 partners from the Eurostat database. The volatilities are built on monthly data with $\mathrm{T}=12$, as a modified version of Hau (2002), to have them in annual frequency. These are defined as the standard deviation for the percentage changes of the REER and NEER over intervals of 1 year.

$$
\begin{aligned}
& \operatorname{VOLREER}_{\text {year }, i}=\left[\frac{1}{T} \sum_{i}\left(\frac{\text { EEER }_{t+12, i}-R E E R_{t, i}}{R E E R_{t, i}}\right)^{2}\right]^{1 / 2} \\
& \operatorname{VOLNEER}_{\text {year }, i}=\left[\frac{1}{T} \sum_{i}\left(\frac{N E E R_{t+12, i}-N E E R_{t, i}}{N E E R_{t, i}}\right)^{2}\right]^{1 / 2}
\end{aligned}
$$

Lastly for the impact of REER misalignments and volatilities on growth, we apply the following setup, in which we estimate the GDP growth (the real GDP growth as percentage change with respect to the previous year, in equation (5) and (6) is $G D P G$ ) in a dynamic panel setup.

We do this by using the REER misalignments (equation (5)) or the volatilities (equation (6) where VOL stands for VOLREER or VOLNEER) in the baseline only along with the government expenditure over GDP (gov) as also applied in Vieira and MacDonald (2012). ${ }^{15}$ The government expenditure (consumption and investment) seemed to be an important factor for GDP growth in the long-run across EU countries before 2004 (Arpaia \& Turrini, 2008). This has also been investigated for the US in the famous paper by Blanchard \& Perotti (2002) and applied recently in Auerbach \& Gorodnichenko $(2012)^{16}$ finding an important but asymmetric effect of government expenditure on GDP.

\footnotetext{
${ }^{13}$ As reported by Schnatz (2011) and Clark \& MacDonald (1999, 2004), HP filtering the fundamentals takes into account the possible misalignments of these variables themselves, giving only the permanent part of them.

${ }^{14}$ The formula to compute the REER and NEER volatilities can be taken from Hau (2002) or Calderon (2004). Hau (2002) uses the same formula but with $\mathrm{T}=36$ months, see equation (26) on p. 620. Calderon (2004) decides to have a 5-year window for the computation of this volatility.

${ }^{15}$ Arpaia \& Turrini (2008) provides and analysis over a sample comprising EU-15 countries over the 1970-2003 period.

${ }^{16}$ In Blanchard \& Perotti (2002) the authors stress the role of both government expenditure and taxation in affecting GDP and their results for post-war US consistently show positive government spending shocks as having a positive effect on output. Auerbach \& Gorodnichenko (2012) conclude that policies that increase government purchases have a much larger impact in recession and, indeed, with US data estimates of the government spending multiplier are different depending on the business cycle: between 0 and 0.5 in expansions, and between 1 and 1.5 in recessions.
} 
We estimate the coefficient for the whole panel of 27 countries; the overvaluations may have a different impact on growth compared to undervaluation cases. In this case we analyse the whole panel introducing a dummy for the cases of undervaluation (defined as negative misalignments), as in Berg \& Miao (2010).

$$
\begin{aligned}
& G D P G_{i, t}=\beta_{1 i} G D P G_{i, t-1}+\beta_{2 i} R E E R \operatorname{Rmis}_{i, t}+\beta_{3 i} X_{i, t}+\varepsilon_{i, t} \\
& G D P G_{i, t}=\beta_{1 i} G D P G_{i, t-1}+\beta_{2 i} V O L_{i, t}+\beta_{3 i} X_{i, t}+\varepsilon_{i, t}
\end{aligned}
$$

Here in vector $X$ we include the government expenditure, the undervaluation dummy and other control factors for the cross-sectional dependence.

In our setup, the role of convergence, normally incorporated in an initial income ${ }^{17}$ variable, is played by the relative GDP per capita into the REER equation and captured also by the lagged value of the GDP growth itself.

\section{Data description}

The data we use to estimate the model covers the period from 1994-2012 with annual frequency for $27 \mathrm{EU}$ members. Luxembourg is not included because the data for foreign capital inflows are not available. For the first part on REER misalignments, the dependent variable is the real effective exchange rate deflated by the CPI vis-à-vis 37 partners. The data are from Eurostat. The same weights have been used to compute the GDP per capita in constant euro relative to the average of partners. The first explanatory variables are the foreign net capital inflows (divided in FDIs, portfolio investments and other investments); these data are taken from IMF World Economic Outlook (WEO). Lastly we used the terms of trade as exports unit value over imports unit value and the Balassa-Samuelson effect represented by the real GDP per capita relative to the partners. The data for the first variable are from World Bank World Development Indicators (WB WDI). The BalassaSamuelson measure is calculated from WB WDI data as well.

In the second part, we have the real GDP growth (as percentage change with respect to the previous year) as the dependent variable, from IMF International Financial Statistics (IFS). The regressors in the baseline are the REER misalignments previously calculated and the general government final consumption expenditure (as a percentage of GDP) from WB WDI (not in relative terms). Lastly, we add a dummy equal to 1 for the cases of real undervaluation (defined as negative misalignments) in the spirit of Berg \& Miao (2010), which also varies over time. In order to get rid of weak and strong cross-sectional dependence ${ }^{18}$, in the robustness checks, we add a weighted foreign GDP growth measure and the world GDP. The weights for the weighted foreign

\footnotetext{
${ }^{17}$ The role of initial income is explained in the neo-classical growth model (Barro, 1991). Here it is seen as proxies for convergence in the EU.

${ }^{18}$ For a distinction between weak and strong cross-sectional dependence, see for instance Sarafidis \& Wansbeek (2012). In a nutshell, unobserved components can be seen as shocks, the impact of which is either global factors (strong CSD) or local (spatially correlated components, weak CSD).
} 
GDP growth (proxy of members' spillovers) have been taken from DG ECFIN, Price and Competitiveness database and are the same as the ones for the REERs computed for 28 EU partner countries. In addition, we add a specification to control for global factors as well, adding world GDP from IMF WEO (in current USD, transformed in an index 2010=100).

\section{Diagnostic and estimation strategy}

For the BEER panel, after having tested the presence of Unit Roots (Im-Pesaran-Shin (2003) test) and cointegration (Pedroni test ${ }^{19}$ ), the results show that most of our variables are non-stationary and the panel is cointegrated both in the full version with all the types of capital flows and the sub-samples. ${ }^{20}$

[Insert Table 1 and 2 around here]

The panel is cointegrated and the differences among countries led us to assume that preference should be given to heterogeneous coefficients. In this case, as proved by Pedroni (2000), the simply panel OLS estimator for the static setup cannot be used because it would be biased. We therefore prefer the GM-FMOLS estimator, which is built as the average of the within FMOLS estimator over the cross-sectional dimension. The Fully Modified OLS (FMOLS) is a semi-parametric correction to the OLS estimator which eliminates the second order bias induced by the endogeneity of the regressors. ${ }^{21}$

The influence of REER misalignments on GDP growth is estimated by using a dynamic ARDL as in equation (5) and (6). In a panel regression model with lagged endogenous variables, the fixed effects estimator (FE) has been proved to be inconsistent for finite $\mathrm{T}$ (Nickell (1981)). The bias in dynamic FE estimator is almost negligible only in the case of T large enough (Roodman (2006)). Standing to this formulation, we may have a problem of endogeneity between the dependent variable and its lag and also among explanatory variables such as between REER misalignments and government expenditure. The solution to this issue is usually found in IV-GMM estimators. However, the moment conditions of the GMM estimators are only valid if there is no serial correlation in the idiosyncratic errors. In addition, GMM methodologies work only if slope coefficients are invariant across the individuals. Instead, in the case of cross-sectional dependence, there are variables and/or residual correlations across panel entities, normally due to common shocks (e.g. recession, crisis...) or spillover effects. Cross-sectional dependence (CSD) and heterogeneity in the slopes can lead to bias in tests results (contemporaneous correlation), not precise estimates and identification problems.

\footnotetext{
${ }^{19}$ This is a revised procedure for cointegration tests in heterogeneous panels with multiple regressors ("Pedroni tests"). We can't apply the Westerlund (2007) test here because our panel does not have enough data for some individuals (minimum requirement -9 observations for each variable for each individual).

${ }^{20} \mathrm{We}$ also tested for the presence of cross-sectional dependence (CSD), but to the best of our knowledge there are no estimators that can deal with CSD in case of a static, cointegrated, unbalanced and heterogeneous panel. The outcome of the tests on CSD is available upon request.

${ }^{21}$ For more details on GM-FMOLS, see Comunale (2015a).
} 
Given this, for the second part about the effect of misalignments on growth we tested for non-stationarity, cross-sectional dependence and cointegration.

[Insert Table 3a, 4a and 5a around here]

We reparametrised our setup into a panel error correction model (PECM), as shown in equation (7) and (8), because our dynamic panel cannot reject non-stationarity in the government expenditure in all the series and it does present cointegration in the more complex specifications. ${ }^{22}$ The reason for this choice is also that this framework allows us to study both the short-term and the long-term influence of REER misalignments on growth. In this case, the estimators we can use are 3, namely the Mean Group (MG), the Pooled Mean Group (PMG) and the Dynamic Fixed Effects (DFE). The MG estimator is the only one that gives heterogeneous coefficients in both the short and long-run analysis and we decide to use it to keep the heterogeneity of our sample of $27 \mathrm{EU}$ countries.

$\Delta G D P G_{i, t}=\phi_{i}\left(G D P G_{i, t-1}-\theta_{0 i}^{\prime}-\theta_{1 i}^{\prime} R E E R m i s_{i, t}-\theta_{2 i}^{\prime} X_{i, t}\right)+\delta_{11 i}^{\prime *} \Delta R E E R m i s_{i, t}+\delta_{21 i}^{\prime *} \Delta X_{i, t}+\mu_{i}+\varepsilon_{i, t}$

$\Delta G D P G_{i, t}=\phi_{i}\left(G D P G_{i, t-1}-\theta_{0 i}^{\prime}-\theta_{1 i}^{\prime} V O L_{i, t}-\theta_{2 i}^{\prime} X_{i, t}\right)+\delta_{11 i}^{\prime *} \Delta V O L_{i, t}+\delta_{21 i}^{\prime *} \Delta X_{i, t}+\mu_{i}+\varepsilon_{i, t}$

The coefficients $\phi$ and $(\phi \cdot \theta)$ represent the long-run effects while the coefficients $\delta$ correspond to the impact of the variables in the short-run. The government expenditure (gov) and the undervaluation dummy are in the vector $X$.

Moreover, using the test developed by Pesaran (2004) we found that the hypothesis of cross-sectional independence in our dynamic panel is indeed strongly rejected. In order to "purify" our panel from the presence of CSD, firstly we add on our right hand side a measure borrowed from the GVAR literature: the trade weighted mean of foreign GDP growth, as this should take out a part of the common factor and therefore substantially reduce the (weak part of) cross-sectional dependence. This new variable can be seen as a measure of spillovers among the EU member countries. The weights for the foreign GDP growth measure are the same as the ones for the REERs computed for $28 \mathrm{EU}$ partner countries and they take into account the "third market effect". ${ }^{23}$ This variable $(F G D P G)$ has been built as the following:

$F G D P G_{i, t}=w_{i, j, t} \cdot G D P G_{j, t}$

where $w_{i, j, t}$ is the trade weight for partner $\mathrm{j}$ of our country $\mathrm{i}$ at time $\mathrm{t}$ and $G D P G_{j, t}$ is the GDP growth of partner $\mathrm{j}$ (with $\mathrm{j}$ going from 1 to 27 ) at time t. In addition, we control for global factors, here proxied by global

\footnotetext{
${ }^{22}$ This has been tested by using Pedroni test, as before.

${ }^{23}$ While import weights are each trading partner's simple share of total EU imports, export weights are double-weighted to account for "third market" effects. They capture the effect of competition faced by EU exporters in foreign markets from both domestic producers and exporters from third countries (Schmitz et al., 2012).
} 
GDP (WGDP), in order to weaken (the strong part of) cross-sectional dependence in equation (7) and (8). This method is inspired by Solberger (2011), which, however, only adds an omitted variable, constant in the crosssection, forcing exogenous common factor dependence. As reported by the same author, simply demeaning the dependent variable would be unsatisfactory.

Summing up, to fix our setup for the presence of CSD, we add in equations (7) and (8), some new control variables inside the vector $\mathrm{X}$ in the long run: the foreign GDP growth $F G D P G$ and/or the world GDP $(W G D P)$. The CSD in this modified setup is not completely eliminated but anyway reduced (See Table $3 \mathrm{~b})^{24}$.

$X=\{$ gov; under $; F G D P G ; W G D P\}$

The tests for our new setup, which includes FGDPG and WGDP, are presented in Table $3 \mathrm{~b}, 4 \mathrm{~b}$ and $5 \mathrm{~b}$. The world GDP is non stationary, while the weighted foreign GDP growth presents some series, which are stationary. The new setups are always strongly cointegrated.

[Insert Table $3 \mathrm{~b}, 4 \mathrm{~b}$ and $5 \mathrm{~b}$ around here]

In order to eliminate entirely the CSD issue in our setup, we need to use a dynamic factor model as in Pesaran \& Tosetti (2011), checking for the role of spillovers and global factors, even if in this way we lose the distinction between the short and the long term. Our setups will become the general specification in equation (11).

$y_{i, t}=\beta_{i}^{\prime} \boldsymbol{x}_{i, t}+\gamma_{i}^{\prime} \boldsymbol{f}_{t}+e_{i, t}$

where $\boldsymbol{x}_{i, t}$ is the vector of observed individual effects (REERmis;VOL;X;dummy) and $\boldsymbol{f}_{t}$ is a vector of $\mathrm{m}$ unobserved common factors (our spillovers or global factors), which affect all the individuals at different times and at different degrees allowing for heterogeneity in the slope represented by the vector $\gamma_{i}=$ $\left(\gamma_{i 1}, \ldots, \gamma_{i m}\right)^{\prime 25}$ In Pesaran \& Tosetti (2011) the authors proposed 3 different estimators for the model: the CCE (Common Correlated Effects) estimator with homogeneous coefficients, the CCEP, which is its pooled version and the CCEMG that stands for CCE Mean Group.

Eberhardt (2012) also provided an alternative estimator to the CCEMG: the Augmented Mean Group (AMG) estimator, which also deals with dynamic, cross-sectional dependent panels with heterogeneous coefficients and it can be used also if the panel is cointegrated. Another difference among AMG and CCEMG is that in the CCEMG, the set of unobservable common factors is treated as a nuisance, something to be accounted for which is not of particular interest for the empirical analysis. Moreover, here we should not use the estimators

\footnotetext{
${ }^{24}$ We applied the test developed by Pesaran (2004), finding a reduced test from over 40 to 16 . The p-value is, however, still equal to zero, which still means that we did not eliminate the CSD issue. In order to do so, we moved to a dynamic factor model setup.

${ }^{25}$ Normally in the dynamic factor models we have also $\boldsymbol{d}_{t}=\left(d_{1 t}, \ldots, d_{n t}\right)$ as the vector of observed common effects. In our setup we do not have observed common time-varying factors.
} 
as in Pesaran \& Tosetti (2011), because they have been designed for micro panel models with "large-T, small-N" (Roodman, 2009). In our case we have 27 countries and 19 years with annual frequency. However, the AMG estimator used in Eberhardt \& Teal (2010) and reported by Eberthardt (2012) has been also applied to a panel with 48 countries and 32 years $(\mathrm{N}>\mathrm{T}$ as in our setup) in these papers.

We therefore decided to use the AMG estimator in our analysis as well as to clean out completely the crosssectional dependence. To summarise briefly the AMG procedure, it is implemented in two steps (Eberhardt, 2012). First of all (Stage (i)), a pooled regression model augmented with year dummies is estimated by first difference OLS, and the coefficients on the (differenced) year dummies are collected. They represent an estimated cross-group average of the evolution of unobservable factors over time ("common dynamic process"). Then secondly (in Stage (ii)), this group-specific regression model is augmented with the estimated common dynamic process from Stage (i): either a) as an explicit variable (as in our case, in which we impose an additional covariate to make these factors explicit) or b) imposed on each group member with a unit coefficient by subtracting the estimated process from the dependent variable. Like in the MG case, each regression model includes an intercept that captures time-invariant fixed effects and as also in the CCEMG estimators, the group-specific model parameters are averaged across the panel. Summing up, the AMG uses an explicit estimate for the unobserved common factors from the Stage (i)), while in the CCEMG they are proxied by the cross-section averages of the dependent variable and of the regressors.

In the last part of this article we provide a robustness check by using a new estimator, the "Common Correlated Effects (Mean Group) - Generalized Method of Moments (CCE-GMM)" by Neal (2015). This estimator extends the already-mentioned CCE (MG) estimator in Pesaran \& Tosetti (2011) and Pesaran (2006), by replacing OLS with GMM, and using lags of the variables to form the instrument set. In this way we can deal with both our main issues: endogeneity and cross-sectional dependence, keeping the heterogeneity in the coefficients. The main drawbacks from the approach by Pesaran \& Tosetti (2011), however, remain.

\section{Results}

\subsection{REER determinants and misalignments}

Concerning the determinants of the REERs, we start looking at different capital flows: FDIs, portfolio and other investments (i.e. bank loans) in the whole EU (Table 6a). For the full sample, the flows are taken all together in column 1 and then one by one in column 2-4. Moreover we make other flows interacting with the percentage of foreign banks over the total number of banks (Table 6b). The main findings are in Column 2 and 5, while the other columns are as in Table 6a and there for comparison reason.

[Insert Table 6a and 6b around here] 
As expected the coefficient for the FDIs is negative for the whole EU (Table 6, column 2) and it is actually driven by the results for the CEECs. ${ }^{26}$ FDIs are normally associated with investments in a longer time perspective and here they have a positive effect on price competitiveness (i.e. negative coefficients for REER). They should have been mainly directed to tradable/productive sectors, although this may not always be the case, as in Estonia's experience of cross-border acquisition of banks.

For the portfolio investments (column 4), we expect the coefficient to be positive (i.e. decrease in price competitiveness in the case of an increase in the portfolio flows). Portfolio investments and other (mainly banking loans) are normally associated with investment in non-tradables and construction. This has been especially true for the Baltic States and some periphery countries like Ireland and Spain. The coefficients for portfolio flows are indeed positive and significant for the entire EU sample, while it is not significant only for the new EU Member States. The portfolio inflows in the latter countries have been generally smaller in comparison with other EU members. Lastly, the coefficient for other flows taken separately is surprisingly negative (it means that an increase in this type of net inflows would affect positively price competitiveness). This outcome may be driven by the different natures of these flows. In case of a high percentage of foreign banks $^{27}$, those can represent basically transfers of liquidity from the bank to the branches in the foreign countries. This is the reason why we also check for the interaction term between other flows and percentage of foreign banks over the total. As in Table $6 \mathrm{~b}$ column (5), the coefficient is strongly positive if "other flows" are interacted with this percentage. If we run our regression adding all the different types of flows we have a significant coefficient for the other investments, i.e. banking loans, both alone and interacted with percentage of foreign banks. In this case (Table 6b, Column 2) also portfolio investments become significantly positive, while FDIs are still not significantly different from zero.

It is also worth noting that the considered period covers both the boom and the bust phase, which means it includes years of huge capital inflows and then from 2010-12 a drop in these funding sources (in gross capital flows relative to pre-crisis levels in general, with the greatest contraction observed for banking flows as reported in Milesi-Ferretti and Tille, 2011).

We double checked our results by using a shorter sample: 1994-2010, in order to analyse the change in coefficients from the crisis time to the ones including the after-crisis/recovery period (2011-2012). The results for the period 1994-2010 are very much in line with the ones based on a longer time span (Table 6a, column 5). The other investments role is slightly higher when all the flows are taken into account and significant at 1 per cent. $^{28}$

\footnotetext{
${ }^{26}$ Detailed results for each country group and the flows taken separately are available upon request.

${ }^{27}$ These data are from the Global Financial Development database of the World Bank.

${ }^{28}$ The results based on the period 1994-2010 are available upon request.
} 
We use the coefficients from Table 6a (column 1), which are about all the EU countries for the longer time span available and include all the types of flows, to build our misalignment measures, as described in Section 3. The results for the REER misalignments for all the countries from 1994 to 2013 are provided in Table 7.

[Insert Table 7 around here]

We find that core countries have been mostly undervalued from the crisis onwards (Fig. 1), while periphery were overvalued starting from 2003-2004. However, Ireland has been constantly undervalued for the period considered and only in 2008-2009 slightly overvalued (Fig. 2). Concerning the new Member States, these are persistently overvalued for the entire time span (Fig. 3).

[Insert Figure 1, 2, 3 around here]

By using the regular approach of BEER, the misalignments in these countries do not follow a cyclical path, which can be counterintuitive. The same results have been found in Comunale (2015a) by using the approach by Lane \& Milesi-Ferretti (2004) and Ricci et al. (2013), in which the flows are replaced by the trade balance or the net foreign asset position. If we use another method to compute the equilibrium and called FEER (Fundamental Effective Exchange Rate), which is based instead on the determinants of the current account ${ }^{29}$, the REER misalignments follow the same cyclical behaviour as the current account ones (Comunale, 2015b).The FEER has been computed as the following:

$\operatorname{REERmis}_{i, t}=\operatorname{CAmis}_{i, t} / \varepsilon_{C A}$

$F E E R_{i, t}=R E E R_{i, t}-R E E R m i s_{i, t}$

where the $C A m i s_{i, t}$ are the misalignments of current account based on its fundamentals (which include some capital flows like FDIs) and $\varepsilon_{C A}$ is the elasticity of the current account on a variation in the REER. ${ }^{30}$ We decide to use both these misalignments in the analysis of the relationship between them and GDP growth.

Firstly we add the BEER-based misalignments for the new Member States together with the misalignments calculated in the same way for all the other EU members. Therefore, we double-check our results for the new Member States only in the robustness check (Section 6.3), by applying both BEER-based and FEER-based misalignments as the regressor for the GDP growth equation. The FEER-based misalignments are taken from Comunale (2015b) and the data are from 2000 to 2012.

\footnotetext{
${ }^{29}$ The FEER is the REER which closed the gap between the equilibrium current account and the one projected by IMF WEO in the medium-long run. For a complete description of this methodology, please see Comunale (2015b).

${ }^{30}$ More details on how the current account misalignments and the FEERs are computed can be found in Comunale (2015b).
} 


\subsection{Misalignments and growth}

For the second part of our analysis, we employ the misalignments as in Table 7 to study their impact on GDP growth in the EU. The setup is as in equation (5). Moreover, we provide this analysis with exchange rate volatilities instead of the misalignments. The main results are shown in Table 8 by using the REER misalignments; Table 9 reports the results with REER and NEER volatilities.

[Insert Table 8 and 9 around here]

The REER misalignments do not play any role in the short-run, while in the long-run their coefficients are highly negative and significant. In case of an increase in the misalignments, which means that the REER presents a real overvaluation and the price competitiveness of the country worsens, the negative effect on GDP growth can be seen in the long-run. This is in line with the recent literature as in Gala \& Lucinda (2006) and Vieira \& MacDonald (2012), which, however, do not provide an analysis for both the short and long-run. Therefore, if a country experienced a huge flow of capitals from abroad (as in the Dutch Disease phenomenon), and especially via banking loans, this will affect its competitiveness negatively, because of an increase in prices of non-tradables and the shift towards less productive and exportable goods and services. The negative effect of these changes on GDP growth will be seen in the long-run.

On top of that, as in the alternative specification in Table 9, REER volatility seems to decrease the GDP growth rate in the short-run, while the NEER volatility has no effect at all. The Dutch Disease can indeed be amplified by increasing volatility of the REER, which lowers the investment volumes in tradables even more (Gylfason et al., 1999). The uncertainty associated with volatility may induce firms to postpone investments and force investors to move from tradable to non-tradable sectors (Cottani et al., 1990). We find this effect only in the short-run, however. We can argue that an increase in REER volatility produces negative effects for GDP growth in the short-run, while a more complex measure of misalignments, which involves terms of trade, Balassa-Samuelson effects, as well as change in capital flows, can influence it more in the long-run.

An increase in government expenditure can reduce the growth rate and it has mainly a short-run effect. Our measure of government expenditure includes both investments and consumption by the general government. The assumption that government spending is unproductive (Leeper et al., 2010) is not very intuitive for government investment. It does depend to which sectors the investments are directed, for instance. In the literature they seem to have a positive effect in the medium-run due to an increase in productivity (Galstyan \& Lane, 2009). However, by using a broad aggregate of government expenditure in our analysis we do not capture the possible positive effects of government investments on growth. In aggregate, the influence of consumption and investments seem to cancel out in the long-run, while in the short-run a negative effect of government consumption is predominant. The government expenditure seemed to be an important factor for GDP growth in the long-run across 15-EU countries before 2004 (Arpaia \& Turrini, 2008), we argue that its 
role considerably changed in the recent decade. Moreover, a change in expenditure may have different policies behind it. For instance, fiscal consolidation has normally negative short-term effects (Clancy et al. 2014 and Coenen et al. 2012) but, as government debt is reduced, this creates space for cuts in distortionary taxes, which can boost growth in the medium and long run. From our result we can argue that the fiscal consolidation, due to the EU membership before and the policies in place after the crisis, exploited only the short-term effects without boosting growth in more of a long-run.

For the real undervaluation dummy, this may play a role in the short-run, helping the growth via an increase in competitiveness, but this outcome is not robust among the specifications. Moreover, if we include the interaction term of this dummy with REER misalignments in the short and long run, the overall effect is not significant. ${ }^{31}$ We don't see a robust asymmetry in affecting growth between positive and negative misalignments. The general effect of the misalignment still holds in our frameworks: it does decrease growth in the long-run.

Now we provide our PECM, adding two proxies for spillovers and global factors, as explained in section 5, to reduce the CSD issue. Moreover, we apply a dynamic factor model, which entirely eliminates the problem but does not show the effects of our regressors and factors in the short and long run separately.

[Insert Table 10 and 11 around here]

The results for REER misalignments are confirmed here, while now the government expenditure and all of the volatilities do not influence the GDP growth rate anymore. The spillovers among the EU members, proxied by the weighted foreign GDP growth, are crucial to explain growth rates. An increase in the GDP growth of the others has, in the long run, a positive effect on the growth rate of our country of interest, confirming the positive role of EU integration in a long-time span. The coefficient is instead negative in the short-run. However, in a period of distress, the countries tend to be closely related and influence each other and the spillovers effects work in a long-term perspective. World GDP, as a proxy for other global factors, has a strong positive influence on growth only in the short-run, while in the long-run it is either non-significant or slightly negative. In case of a big global recession as in 2008-2009, the effect on growth is pro-cyclical and affects all countries in the sample as well. In the long-run, the effect seems to fade away, most likely because of policy actions by the countries to counteract the crisis.

Lastly, we used the dynamic factor model setup for our purposes and the results are provided respectively in Table 12 and 13 for REER misalignments and exchange rate volatilities.

[Insert Table 12 and 13 around here]

\footnotetext{
${ }^{31}$ We also apply the interaction term only for the short-run; in this case only the coefficient is negative and significant but only in the simplest setup (Table 8). All these robustness checks are available upon request.
} 
The results concerning the REER misalignments and the volatilities are confirmed and remain very robust in magnitude with respect to the setups with the corrections for CSD (Table 10 and 11). Other unobserved common factors (spillovers and global factors) are always significant and positive. This reinforces the idea that these factors are indeed crucial for GDP growth in the EU.

As an alternative estimation for the dynamic factor model setup, we apply the CCE (MG)-GMM estimator by Neal (2015), which fully correct for both endogeneity and cross-sectional dependence, keeping the heterogeneity in the coefficients. In the CCE (MG)-GMM setups with Instrumental Variables (IV) (Table $14)^{32}$ the coefficient for the REER misalignment has the wrong sign even if it is not significant anymore. This can be due to the fact that this approach does not allow us to split into short and long-term effects, and probably in this case the short-term lack of significance prevails. ${ }^{33}$ Lastly, the cross section average of the dependent variables is always extremely significant and this can be seen as other ways to make explicit the unobserved common factors possibly related to GDP growth in the EU 27. It is, however, good to recall that in the estimators coming from the original Pesaran \& Tosetti's (2011) CCEMG, the set of unobservable common factors is treated as a nuisance, something to be accounted for, which is not of particular interest for the empirical analysis and, in addition, they have been designed for micro panel models with "large-T, smallN" (Roodman, 2009). This is the reason why we apply this method only as a robustness check.

[Insert Table 14 around here]

\subsection{Other robustness checks}

As a first robustness check we run our regressions without the Netherlands, which is a clear outlier on the REER misalignments (see Table 7 for the data on the misalignments country by country). The results are the same in terms of coefficients signs and significance and very much in line with the ones for the full sample in magnitude as well. ${ }^{34}$

Concerning the new Member States, these are persistently overvalued for the entire time span. By using the regular approach of BEER, the misalignments in these countries do not follow a cyclical path, which can be counterintuitive, as explained in Section 6.1. Therefore, we double-check our results for the new Member

\footnotetext{
${ }^{32}$ We report only the results for REER misalignments and REER volatility, in case of IV-GMM. The NEER volatility is never significant, as in the other specifications. The results for the REER misalignments and the volatilities are very robust by using the simple GMM (without Instrumental Variables). All the results are available upon request.

${ }^{33}$ In fact in our baseline specification (as in Table 8) the short-term coefficient for the REER misalignments are positive but not significant.

${ }^{34}$ The coefficients for the REER misalignments are slightly bigger for the sample without the Netherlands. All the results are available upon request.
} 
States only (11 countries) by applying both BEER-based and FEER ${ }^{35}$-based misalignments as a regressor for the GDP growth equation with the precise correction for CSD (AMG as in Table 12). The "FEER-based" misalignments are taken from Comunale (2015b) and the data concerns the years between 2000 and $2012 .{ }^{36}$

\section{[Insert Table 15 around here]}

By using the "BEER-based" misalignments, the coefficients for the CEECs are still negative but the magnitude is doubled with respect to the whole sample.

If we add the other measure of misalignments, based on an equilibrium rate, which closes the current account gap ("FEER-based), the results are extremely different. This is indeed because of the way the different equilibrium values are computed ${ }^{37}$ and the relative importance we want to give to REER itself or to close the gap in the current account. With the "FEER-based" misalignment values, the coefficient for the CEECs becomes positive but loses significance when we add the undervaluation dummy, signalling that this result is not robust. The way we measure the equilibrium REER is also key for our estimation of the GDP growth. If we are interested in rebalancing the current account, having a positive misalignment with respect to the rate which should be useful for this purpose (i.e. we are in a boom phase and the CEECs are overvalued), will give us an extra boost in GDP growth instead of depressing the economy because of a decrease in price competitiveness. However, in bust periods the negative misalignments will drag the GDP growth down as well. This seems to be very much related to the current account behaviour rather than to the REER itself.

We also checked for the role of REER volatility, but decomposed in NEER and CPI volatility ${ }^{38}$ (in relative terms with respect to the world CPI volatility ${ }^{39}$ ). Therefore, we add in our baseline setups (PECM as Table 9 and Table 11 with foreign GDP growth and world GDP) both NEER and relative CPI volatilities (Table 16, in which we also report the main results from Table 9 and 11 to facilitate comparisons).

[Insert Table 16 around here]

Adding relative CPI volatility together with NEER volatility in the baseline PECM without controls for crosssectional dependence, gives some interesting outcomes: i) the CPI volatility is never significant ${ }^{40}$; ii) the NEER volatility is negative and significant in the short-run. The magnitude of the coefficient of NEER volatility is similar to the one of REER volatility; hence we may argue that GDP growth in the short-run is

\footnotetext{
${ }^{35}$ This is the rate that closes the gap between the current account and its equilibrium value.

${ }^{36}$ The years currently available are namely: 2000; 2004; 2007; 2010 and 2012. I apply a simple linear interpolation in order to have the complete time series.

${ }^{37}$ See section 6.1 for more details.

${ }^{38}$ The data for CPI index are from IMF IFS. The CPI volatilities have been computed by using the same formula as for REER and NEER volatilities (equations (3) and (4)).

${ }^{39}$ The relative CPI volatility is calculated as the following: $C P I \_v o l_{i, t} / C P I \_v o l_{w o r l d, t}$. We also run the regressions with simple CPI volatilities (not in relative terms), these results are available upon request.

${ }^{40}$ It becomes significant only in the long-run if not taken in relative terms.
} 
more influenced by volatility in the exchange rates than in relative prices. However in the long-run the volatility of NEER becomes positive, which is somehow counter-intuitive, i.e. the more volatile the currency the higher is GDP growth rate in the long-run. Therefore, we checked for these conclusions by adding the volatilities in the setup with foreign GDP growth and world GDP in order to control for cross-sectional dependence. The results in this case are instead very robust with respect to the one with REER volatility only (Table 11), in which NEER or REER volatilities do not play any role in the short or long-run and also here the CPI volatility is never significant. With simple CPI volatilities (not in relative terms), these results are very similar and extremely robust. We also run our growth regression adding CPI inflation ${ }^{41}$, as in MacDonald \& Vieira (2010) and recently in Owoundi (2016). The results for the REER misalignments are very much in line with the ones in the dynamic factor model (and inflation is not significant). However, in the panel ECM (with and without correction for the cross-sectional dependence) the magnitude of these coefficients is overall bigger. The CPI inflation has a negative influence on growth in the long-run, while it seems to be positive in a more short-run ${ }^{42}$.

Ultimately, we add a time-varying variable for the de facto exchange rate regime ${ }^{43}$, looking at how this may influence GDP growth together with REER misalignments. The coefficient of this last regressor is never significant however all the other outcomes are very robust ${ }^{44}$ with respect to the PECM (with or without the corrections for CSD) and the dynamic factor model estimated by AMG (with or without undervaluation dummy.

The last check concerns possible structural breaks. We run our exercise only for the year before 2009, i.e. the whole pre-crisis period 1994-2008, and then we draw a comparison with the full sample, which is until 2012. The REER misalignments are significant and very robust in any case. ${ }^{45}$ We repeat this analysis excluding the boom years before the EU enlargement, i.e. 1994-2003. The coefficient for REER misalignment becomes

\footnotetext{
${ }^{41}$ The inflation rates are taken from IMF IFS for the period 1994-2012 (hence the data include iperinflation in some CEECs in the 90s) as percentage change with respect to the previous year. As an additional robustness check we also used data from Eurostat (19962012) as annual average rate of change in HICP $(2015=100)$. By using the dynamic factor model the results for the coefficient of the REER misalignments are quite robust with respect to the baseline (Table 12). The magnitude is slightly bigger when inflation is included. The inflation rate is itself not significant. In the panel ECM the significance of REER misalignments is not assured in all the specification, while inflation becomes significant in some cases for the long-run.

${ }^{42}$ All these results are available upon request.

43 As in Comunale (2015a), the data from 1994-2007 are from Reinhart \& Rogoff website (dataset for Ilzetzki, Reinhart \& Rogoff (2008)). These data are based on the IMF De Facto Classification of Exchange Rate Regimes (Coarse classification codes). For the period 2008-2012: Annual Report on Exchange Arrangements and Exchange Restrictions (various reports year until 2012).

The classification codes are: 1 = no separate legal tender, pre-announced peg or currency board arrangement, pre-announced horizontal band that is narrower than or equal to $+/-2 \%$, de facto peg. $2=$ pre-announced crawling peg, pre-announced crawling band that is narrower than or equal to $+/-2 \%$, de facto crawling peg, de facto crawling band that is narrower than or equal to $+/-2 \%$. $3=$ preannounced crawling band that is wider than or equal to $+/-2 \%$, de facto crawling band that is narrower than or equal to $+/-5 \%$, moving band that is narrower than or equal to $+/-2 \%$ (i.e., allows for both appreciation and depreciation over time), managed floating. $4=$ freely floating, 5 = freely falling.

${ }^{44}$ Results are available upon request.

45 This is true by using either a PECM or a dynamic factor model with or without undervaluation dummy or corrections for CSD for the PECM. All these robustness checks are available upon request. We cannot perform the same analysis for the period 2009-2012 because our sample is too small.
} 
insignificant ${ }^{46}$ in this occasion. The REER misalignments started playing an important role for GDP growth (in the long-run) only after 2004, where indeed they grow a lot in the periphery and keep growing in CEE new Member States.

\section{Conclusions, policy implications and further research}

In this article we study the impact of real effective exchange rate (REER) misalignments, based on long-run REER determinants including different types of foreign capital inflows, and exchange rate volatilities on GDP growth in the EU both in the short and long run. We also analyse the roles of unobserved common factors as global events and spillovers among the members and how these can affect GDP growth.

We find that the core countries have been mostly undervalued from the crisis onwards, while periphery were overvalued starting from 2003-2004, as expected. Concerning the new Member States, these are persistently overvalued for the entire time span. The results seem to be generally driven by the inflows of banking loans more than by FDIs or portfolio investments.

In the second stage we study the influence of misalignments on growth. As for this paper, we estimate the GDP growth in a dynamic panel setup by using the REER misalignments or the exchange rate volatilities along with the government expenditure and a real undervaluation dummy. We find that the REER misalignments, associated with inflows, have been a further cause of the decline in GDP, in the long-run perspective, while they do not play a role in the short run. Therefore, if a country experienced a huge flow of capitals from abroad (as the Dutch Disease phenomenon), and especially via banking loans, this will affect its competitiveness negatively, because of an increase in prices of non-tradables and the shift to less productive and exportable goods and services. The volatilities in the exchange rates and the undervaluation dummy are not robust in affecting GDP growth, while spillovers and global factors seem to matter in all the specifications both in the short and long run.

Further research may concern to strengthen the relationship between REER misalignments, other misalignments/gaps and growth. Moreover we believe that a useful extension of this framework can be done by analysing the Value Added REER (VAREER) determinants (this measure has been calculated by Bems \& Johnson, 2012; 2015) and hence to compute the misalignments. This measure is based on REER with weights coming from the value added and takes better into account the global supply linkages. On the top of that, we have seen that the way we measure the equilibrium REER matters, and can be related to the behaviour of the current account more to the one of the rate itself. This is the reason why, we are working on the relationship between different misalignments and growth.

\footnotetext{
${ }^{46}$ We checked for an alternative period 1994-2004, and the coefficient turns significant again.
} 
ANNEX: TABLES AND FIGURES

Table 1. Stationarity test: Im-Pesaran-Shin (IPS) panel unit root test

\begin{tabular}{|l|c|c|c|c|}
\hline & \multicolumn{4}{c|}{ IPS t-bar -test } \\
\hline \multicolumn{1}{|c|}{ Variable } & \multicolumn{2}{c|}{ No trend } & \multicolumn{2}{c|}{ Trend } \\
\hline REER & t-stat & p-value & t-stat & p-value \\
\hline FDI/GDP & $-\mathbf{1 . 9 1 7 2}$ & $\mathbf{0 . 0 2 7 6 *}$ & $-\mathbf{2 . 2 3 3 7}$ & $\mathbf{0 . 0 1 2 8 *}$ \\
\hline Other investments/GDP & -5.0073 & 0.0000 & -3.5363 & 0.0002 \\
\hline Portfolio investments/GDP & -3.4672 & 0.0003 & -1.5606 & $0.0593^{*}$ \\
\hline Terms of trade & -4.2583 & 0.0000 & -2.2698 & $0.0116^{*}$ \\
\hline Relative GDP per capita & -0.0779 & $0.4689 *$ & -0.2902 & $0.3858^{*}$ \\
\hline
\end{tabular}

Note: In the IPS-test, one lag has been imposed. IPS can be used in case of unbalanced panel, but requires that there are no gaps in each individual time series. Other tests require that the panels are strongly balanced. The variable in bold font is the dependent variable in our equation. Null hypothesis assumes that all series are non-stationary. *We accept the null of non-stationarity or we cannot reject it at $1 \%$ level.

Table 2. Pedroni test for cointegration

\begin{tabular}{|l|c|}
\hline & Panel group RHO-stat \\
\hline Full sample (FDI; other; portfolio) & $4.58^{* * *}$ \\
\hline Only FDI & $1.99^{* *}$ \\
\hline Only other investments & $2.14^{* *}$ \\
\hline Only portfolio investments & $1.76^{* *}$ \\
\hline
\end{tabular}

Note: This is a revised procedure for cointegration tests in heterogeneous panels with multiple regressors ("Pedroni tests"). We applied 1 lag (no trend). All reported values are distributed $\mathrm{N}(0.1)$ under null of no cointegration. In case of very small panel (as it is here) in Pedroni (2004) is explained that group RHO-stat is better because less distortive and more conservative. If group RHO-stat Panel $=-$ 2.336 then p-value $=0.010$ (Source: Maeso-Fernandez et al, 2004) with $\mathrm{N}=25$. In my case $\mathrm{N}=27$, we can apply 2-tails t-stat (Rho-stat is distributed approximately as Student's $t$ distribution with $(\mathrm{n}-2)$ degrees of freedom under the null hypothesis): $10 \%$ with rejection of the null if it is higher than $1.316(*) ; 5 \%$ rejection if higher than $1.708(* *) ; 1 \%$ rejection if higher than $2.485(* * *)$ 
Table 3a. Cross-sectional independence test (Pesaran's test)

\begin{tabular}{|l|c|c|}
\hline & Test & Probability \\
\hline Table 8 - Column (1-2) - (L.gdpgr; REERmis; gov) & 40.317 & 0.0000 \\
\hline Table 8 - Column (3-4) - (L.gdpgr; REERmis; gov; under) & 40.195 & 0.0000 \\
\hline Table 9 - Column (1-2) - (L.gdpgr; REERVOL; gov) & 44.221 & 0.0000 \\
\hline Table 9 - Column (3-4) - (L.gdpgr; REERVOL; gov;under) & 42.279 & 0.0000 \\
\hline Table 9 - Column (5-6) - (L.gdpgr; NEERVOL; gov) & 44.246 & 0.0000 \\
\hline Table 9 - Column (7-8) - (L.gdpgr; NEERVOL; gov; under) & 42.172 & 0.0000 \\
\hline
\end{tabular}

Note: Pesaran's test for cross-sectional independence following the methods shown in Pesaran (2004). Pesaran's statistic follows a standard normal distribution and it is able to handle balanced and unbalanced panels. It tests the hypothesis of cross-sectional independence in panel data models. Here L.gdpgr is the first lag of the dependent variable: GDP growth; REERmis are the misalignments previously calculated; REERVOL is the volatility of REER; NEERVOL is the volatility of NEER; gov is the government expenditure over GDP; under is the real undervaluation dummy.

Table 4a. Stationarity test: second generation $t$-test by Pesaran (2007) for unit roots in heterogeneous panels with cross-section dependence (CIPS)

\begin{tabular}{|l|c|c|}
\hline Variable & & \\
\hline & Z[t-bar $]$ & p-value \\
\hline gdpg & $\mathbf{- 2 . 4 2 3}$ & $\mathbf{0 . 0 0 8}$ \\
\hline REERmis & -5.770 & 0.000 \\
\hline REERVOL & -10.573 & 0.000 \\
\hline NEERVOL & -13.367 & 0.000 \\
\hline gov* $^{*}$ & -0.554 & 0.290 \\
\hline
\end{tabular}

Note: Null hypothesis assumes that all series are non-stationary, the alternative is that some series are stationary. 1 lag has been imposed for the dependent variable. This $t$-test is also based on Augmented Dickey-Fuller statistics as IPS (2003) but it is augmented with the cross section averages of lagged levels and first-differences of the individual series (CADF statistics). ${ }^{47} *$ means nonstationarity for all series (cannot reject the null or we accept the null). Here gdpgr is the GDP growth; REERmis are the misalignments previously calculated; REERVOL is the volatility of REER; NEERVOL is the volatility of NEER; gov is the government expenditure over GDP.

${ }^{47}$ The command in Stata is called -pescadf- and it has been built by Piotr Lewandowski, Warsaw School of Economics, Institute for Structural Research. 
Table 5a. Pedroni test for cointegration

\begin{tabular}{|l|c|}
\hline & Panel group RHO-stat \\
\hline Table 8 - Column (1-2) - (L.gdpgr; REERmis; gov) & -0.36 \\
\hline Table 8 - Column (3-4) - (L.gdpgr; REERmis; gov;under) & $1.52^{*}$ \\
\hline Table 9 - Column (1-2) - (L.gdpgr; REERVOL; gov) & -0.46 \\
\hline Table 9 - Column (3-4) - (L.gdpgr; REERVOL; gov;under) & $1.60^{*}$ \\
\hline Table 9 - Column (5-6) - (L.gdpgr; NEERVOL; gov) & -0.49 \\
\hline Table 9 - Column (7-8) - (L.gdpgr; NEERVOL; gov;under) & $1.64^{*}$ \\
\hline
\end{tabular}

Note: This is a revised procedure for cointegration tests in heterogeneous panels with multiple regressors ("Pedroni tests"). We applied $1 \mathrm{lag}$ (no trend). All reported values are distributed N (0.1) under null of no cointegration. In case of very small panel (as it is here) in Pedroni (2004) is explained that group RHO-stat is better because less distortive and more conservative. If group RHO-stat Panel = -2.336 then $\mathrm{p}$-value $=0.010$ (Source: Maeso-Fernandez et al, 2004) with $\mathrm{N}=25$. In my case $\mathrm{N}=27$, we can apply 2-tails $t$-stat (Rhostat is distributed approximately as Student's $t$ distribution with $(\mathrm{n}-2)$ degrees of freedom under the null hypothesis): $10 \%$ with rejection of the null if it is higher than $1.316(*) ; 5 \%$ rejection if higher than $1.708(* *) ; \mathbf{1 \%}$ rejection if higher than $2.485(* * *)$.

Here L.gdpgr is the first lag of the dependent variable: GDP growth; REERmis are the misalignments previously calculated; REERVOL is the volatility of REER; NEERVOL is the volatility of NEER; gov is the government expenditure over GDP; under is the real undervaluation dummy.

Table 3b. Cross-sectional independence test (Pesaran's test) with fgdpg and wgdp

\begin{tabular}{|l|c|c|}
\hline & Test & Probability \\
\hline Table 8 - Column (1-2) - (L.gdpgr; REERmis; gov) & 16.027 & 0.000 \\
\hline Table 8 - Column (3-4) - (L.gdpgr; REERmis; gov; under) & 16.026 & 0.000 \\
\hline Table 9 - Column (1-2) - (L.gdpgr; REERVOL; gov) & 15.966 & 0.000 \\
\hline Table 9 - Column (3-4) - (L.gdpgr; REERVOL; gov;under) & 16.075 & 0.000 \\
\hline Table 9 - Column (5-6) - (L.gdpgr; NEERVOL; gov) & 16.233 & 0.000 \\
\hline Table 9 - Column (7-8) - (L.gdpgr; NEERVOL; gov; under) & 16.371 & 0.000 \\
\hline
\end{tabular}

Note: Pesaran's test for cross-sectional independence following the methods shown in Pesaran (2004). Pesaran's statistic follows a standard normal distribution and it is able to handle balanced and unbalanced panels. It tests the hypothesis of cross-sectional independence in panel data models. Here L.gdpgr is the first lag of the dependent variable: GDP growth; REERmis are the misalignments previously calculated; REERVOL is the volatility of REER; NEERVOL is the volatility of NEER; gov is the government expenditure over GDP; under is the real undervaluation dummy. Fgdpg is the weighted foreign GDP growth and wgdp is the nominal world GDP $2010=100$. 
Table 4b. Stationarity test: second generation $t$-test by Pesaran (2007) for unit roots in heterogeneous panels with cross-section dependence (CIPS) with fgdpg and wgdp

\begin{tabular}{|l|c|c|}
\hline Variable & & \\
\hline & Z[t-bar] & p-value \\
\hline gdpg & $\mathbf{- 2 . 4 2 3}$ & $\mathbf{0 . 0 0 8}$ \\
\hline REERmis & -5.770 & 0.000 \\
\hline REERVOL & -10.573 & 0.000 \\
\hline NEERVOL & -13.367 & 0.000 \\
\hline gov* & -0.554 & 0.290 \\
\hline fgdpg & -9.658 & 0.000 \\
\hline wgdp* & 22.160 & 1.000 \\
\hline
\end{tabular}

Note: Null hypothesis assumes that all series are non-stationary, the alternative is that some series are stationary. 1 lag has been imposed for the dependent variable. This $t$-test is also based on Augmented Dickey-Fuller statistics as IPS (2003) but it is augmented with the cross section averages of lagged levels and first-differences of the individual series (CADF statistics). ${ }^{48} *$ means nonstationarity for all series (cannot reject the null or we accept the null). Here gdpgr is the GDP growth; REERmis are the misalignments previously calculated; REERVOL is the volatility of REER; NEERVOL is the volatility of NEER; gov is the government expenditure over GDP. Fgdpg is the weighted foreign GDP growth and $w g d p$ is the nominal world GDP 2010=100.

Table 5b. Pedroni test for cointegration with fgdpg and wgdp

\begin{tabular}{|l|c|}
\hline & Panel group RHO-stat \\
\hline Table 8 - Column (1-2) - (L.gdpgr; REERmis; gov) & $2.35^{* *}$ \\
\hline Table 8 - Column (3-4) - (L.gdpgr; REERmis; gov;under) & $4.19^{* * *}$ \\
\hline Table 9 - Column (1-2) - (L.gdpgr; REERVOL; gov) & $2.52^{* * *}$ \\
\hline Table 9 - Column (3-4) - (L.gdpgr; REERVOL; gov;under) & $4.06^{* * *}$ \\
\hline Table 9 - Column (5-6) - (L.gdpgr; NEERVOL; gov) & $2.32^{* *}$ \\
\hline Table 9 - Column (7-8) - (L.gdpgr; NEERVOL; gov;under) & $3.95^{* * *}$ \\
\hline
\end{tabular}

Note: This is a revised procedure for cointegration tests in heterogeneous panels with multiple regressors ("Pedroni tests"). We applied 1 lag (no trend). All reported values are distributed $N(0,1)$ under null of no cointegration. In case of very small panel (as it is here) in Pedroni (2004) is explained that group RHO-stat is better because less distortive and more conservative. If group RHO-stat Panel = -2.336 then $p$-value $=0.010$ (Source: Maeso-Fernandez et al, 2004) with $\mathrm{N}=25$. In my case $\mathrm{N}=27$, we can apply 2-tails $t$-stat (Rhostat is distributed approximately as Student's t distribution with $(\mathrm{n}-2)$ degrees of freedom under the null hypothesis): $10 \%$ with rejection of the null if it is higher than $1.316(*) ; 5 \%$ rejection if higher than $1.708(* *) ; \mathbf{1 \%}$ rejection if higher than $2.485(* * *)$.

Here L.gdpgr is the first lag of the dependent variable: GDP growth; REERmis are the misalignments previously calculated; REERVOL is the volatility of REER; NEERVOL is the volatility of NEER; gov is the government expenditure over GDP; under is the real undervaluation dummy. Fgdpg is the weighted foreign GDP growth and wgdp is the nominal world GDP 2010=100.

${ }^{48}$ The command in Stata is called -pescadf- and it has been built by Piotr Lewandowski, Warsaw School of Economics, Institute for Structural Research. 
Table 6a. REER determinants for EU27 divided by types

\begin{tabular}{lccccc} 
& EU27 & EU27 & EU27 & EU27 & EU27 (2010) \\
\hline \multirow{4}{*}{ VARIABLES } & $(1)$ & $(2)$ & $(3)$ & $(4)$ & $(5)$ \\
& CPI REER & CPI REER & CPI REER & CPI REER & CPI REER \\
FDI & 37 & 37 & 37 & 37 & 37 \\
& & & & & \\
OTHER (bank loans) & 0.25 & $-0.06^{* * *}$ & & & 0.26 \\
& $(0.11)$ & $(0.12)$ & & & $(0.11)$ \\
PORTFOLIO & $0.15^{*}$ & & $-0.33^{* * *}$ & & $0.18^{* * *}$ \\
& $(0.07)$ & & $(0.05)$ & & $(0.12)$ \\
ln_tot & 0.19 & & & $0.22^{* * *}$ & 0.29 \\
& $(0.11)$ & & & $(0.14)$ & $(0.08)$ \\
ln_yd & $0.03 * *$ & 0.06 & $-0.06^{* * *}$ & $0.08^{* *}$ & 0.03 \\
& $(0.041)$ & $(0.043)$ & $(0.044)$ & $(0.043)$ & $(0.041)$ \\
constant & $0.17^{* * *}$ & $0.19^{* * *}$ & $0.27 * * *$ & $0.28^{* * *}$ & $0.49^{* * *}$ \\
& $(0.05)$ & $(0.06)$ & $(0.06)$ & $(0.06)$ & $(0.08)$ \\
& $5.04^{* * *}$ & $4.96^{* * *}$ & $5.07^{* * *}$ & $5.02^{* * *}$ & $5.09^{* * *}$ \\
& $(0.02)$ & $(0.02)$ & $(0.02)$ & $(0.02)$ & $(0.02)$ \\
\hline
\end{tabular}

Table 6b: REER determinants for EU27 divided by types and with \% foreign banks

\begin{tabular}{|c|c|c|c|c|c|c|}
\hline & EU27 & EU27 & EU27 & EU27 & EU27 & EU27 \\
\hline VARIABLES & $\begin{array}{c}(1) \\
\text { CPI REER } \\
37 \\
\end{array}$ & $\begin{array}{c}(2) \\
\text { CPI REER } \\
37\end{array}$ & $\begin{array}{c}(3) \\
\text { CPI REER } \\
37\end{array}$ & $\begin{array}{c}(4) \\
\text { CPI REER } \\
37\end{array}$ & $\begin{array}{c}(5) \\
\text { CPI REER } \\
37\end{array}$ & $\begin{array}{c}(6) \\
\text { CPI REER } \\
37\end{array}$ \\
\hline FDI & $\begin{array}{c}0.25 \\
(0.11)\end{array}$ & $\begin{array}{c}0.17 \\
(0.11)\end{array}$ & $\begin{array}{c}-0.06 * * * \\
(0.12)\end{array}$ & & & \\
\hline OTHER & $\begin{array}{l}0.15^{*} \\
(0.07)\end{array}$ & & & $\begin{array}{c}-0.33 * * * \\
(0.05)\end{array}$ & $\begin{array}{c}-0.62 * * * \\
(0.36)\end{array}$ & \\
\hline Other*fbank & & $\begin{array}{l}1.70 * \\
(1.08)\end{array}$ & & & $\begin{array}{c}2.73 * * * \\
(2.57)\end{array}$ & \\
\hline PORTFOLIO & $\begin{array}{c}0.19 \\
(0.11)\end{array}$ & $\begin{array}{c}0.26^{* * * *} \\
(0.10)\end{array}$ & & & & $\begin{array}{c}0.22 * * * \\
(0.14)\end{array}$ \\
\hline ln_tot & $\begin{array}{l}0.03 * * \\
(0.041)\end{array}$ & $\begin{array}{c}0.13 \\
(0.041)\end{array}$ & $\begin{array}{c}0.06 \\
(0.043)\end{array}$ & $\begin{array}{c}-0.06^{* * * *} \\
(0.044)\end{array}$ & $\begin{array}{c}-0.002 * * * \\
(0.042)\end{array}$ & $\begin{array}{l}0.08 * * \\
(0.043)\end{array}$ \\
\hline ln_yd & $\begin{array}{c}0.17 * * * \\
(0.05)\end{array}$ & $\begin{array}{c}0.14 * * * \\
(0.05)\end{array}$ & $\begin{array}{c}0.19 * * * \\
(0.06)\end{array}$ & $\begin{array}{c}0.27 * * * \\
(0.06)\end{array}$ & $\begin{array}{c}0.17 * * * \\
(0.06)\end{array}$ & $\begin{array}{c}0.28^{* * *} \\
(0.06)\end{array}$ \\
\hline constant & $\begin{array}{c}5.04 * * * \\
(0.02)\end{array}$ & $\begin{array}{c}4.98 * * * \\
(0.02)\end{array}$ & $\begin{array}{c}4.96 * * * \\
(0.02)\end{array}$ & $\begin{array}{c}5.07 * * * \\
(0.02)\end{array}$ & $\begin{array}{c}4.98 * * * \\
(0.02)\end{array}$ & $\begin{array}{c}5.02 * * * \\
(0.02)\end{array}$ \\
\hline
\end{tabular}

Note: Standard errors in parentheses $* * * \mathrm{p}<0.01, * * \mathrm{p}<0.05, * \mathrm{p}<0.1$. EU27 is EU as in 2014 without Luxembourg. FDI represents FDIs net inflows over GDP; PORTFOLIO are the portfolio net inflows over GDP; OTHER are other foreign investments, i.e. mainly banking loans, over GDP; ln_tot is the logarithm of the terms of trade and $l n \_y d$ is the logarithm of the relative GDP per capita. fbank is \% foreign banks over total banks from GFD Database of the World Bank. 


\section{Table 7. REER misalignments}

\begin{tabular}{|c|c|c|c|c|c|c|c|c|c|c|c|c|c|c|c|c|c|c|c|}
\hline & 1994 & 1995 & 1996 & 1997 & 1998 & 1999 & 2000 & 2001 & 2002 & 2003 & 2004 & 2005 & 2006 & 2007 & 2008 & 2009 & 2010 & 2011 & 2012 \\
\hline Austria & 0.05 & 0.08 & 0.05 & 0.01 & 0.00 & -0.02 & -0.05 & -0.05 & -0.05 & -0.02 & -0.02 & -0.02 & -0.03 & -0.02 & -0.02 & -0.01 & -0.04 & -0.03 & -0.05 \\
\hline Belgium & 0.05 & 0.07 & 0.04 & -0.01 & -0.01 & -0.03 & -0.06 & -0.05 & -0.05 & -0.01 & 0.00 & -0.01 & 0.00 & 0.00 & 0.03 & 0.03 & 0.01 & 0.02 & 0.00 \\
\hline Bulgaria & -0.59 & -0.05 & -0.23 & 0.04 & 0.16 & 0.16 & 0.19 & 0.25 & 0.27 & 0.28 & 0.30 & 0.30 & 0.33 & 0.37 & 0.46 & 0.50 & 0.49 & 0.51 & 0.49 \\
\hline Croatia & -0.13 & 0.16 & 0.15 & 0.15 & 0.17 & 0.11 & 0.10 & 0.14 & 0.15 & 0.14 & 0.15 & 0.16 & 0.18 & 0.18 & 0.23 & 0.24 & 0.22 & 0.21 & 0.20 \\
\hline Cyprus & -0.04 & 0.00 & 0.01 & -0.01 & 0.00 & -0.03 & -0.04 & -0.03 & -0.01 & 0.04 & 0.05 & 0.04 & 0.04 & 0.03 & 0.05 & 0.06 & 0.04 & 0.06 & 0.06 \\
\hline Czech Republic & -0.23 & -0.20 & -0.13 & -0.11 & -0.04 & -0.06 & -0.04 & 0.02 & 0.12 & 0.09 & 0.09 & 0.14 & 0.18 & 0.21 & 0.35 & 0.31 & 0.32 & 0.35 & 0.32 \\
\hline Denmark & -0.07 & -0.04 & -0.05 & -0.08 & -0.08 & -0.09 & -0.13 & -0.11 & -0.09 & -0.04 & -0.04 & -0.04 & -0.04 & -0.04 & -0.02 & 0.01 & -0.03 & -0.03 & -0.05 \\
\hline Estonia & -0.26 & -0.06 & 0.06 & 0.06 & 0.13 & 0.13 & 0.10 & 0.13 & 0.14 & 0.15 & 0.16 & 0.17 & 0.18 & 0.23 & 0.31 & 0.33 & 0.32 & 0.33 & 0.34 \\
\hline Finland & 0.04 & 0.12 & 0.08 & 0.03 & 0.02 & 0.00 & -0.05 & -0.03 & -0.02 & 0.02 & 0.01 & -0.01 & -0.02 & -0.01 & 0.01 & 0.03 & -0.01 & -0.01 & -0.03 \\
\hline France & 0.02 & 0.05 & 0.06 & 0.01 & 0.01 & -0.02 & -0.07 & -0.07 & -0.06 & -0.01 & 0.01 & 0.00 & 0.00 & 0.01 & 0.03 & 0.03 & -0.01 & -0.01 & -0.04 \\
\hline Germany & 0.09 & 0.13 & 0.10 & 0.04 & 0.03 & 0.00 & -0.06 & -0.06 & -0.05 & 0.00 & 0.01 & 0.00 & 0.00 & 0.02 & 0.02 & 0.03 & -0.02 & -0.03 & -0.06 \\
\hline Greece & -0.06 & 0.05 & 0.09 & 0.09 & 0.04 & 0.04 & -0.03 & -0.02 & 0.00 & 0.04 & 0.05 & 0.05 & 0.05 & 0.05 & 0.07 & 0.09 & 0.08 & 0.09 & 0.06 \\
\hline Hungary & -0.33 & -0.16 & -0.14 & -0.09 & -0.10 & -0.08 & -0.07 & 0.01 & 0.10 & 0.10 & 0.15 & 0.16 & 0.10 & 0.21 & 0.24 & 0.18 & 0.21 & 0.22 & 0.22 \\
\hline Ireland & -0.13 & -0.11 & -0.10 & -0.10 & -0.17 & -0.20 & -0.24 & -0.22 & -0.17 & -0.08 & -0.05 & -0.05 & -0.04 & -0.01 & 0.03 & 0.01 & -0.06 & -0.08 & -0.13 \\
\hline Italy & -0.06 & -0.13 & -0.02 & -0.03 & -0.02 & -0.04 & -0.09 & -0.08 & -0.06 & 0.00 & 0.01 & 0.01 & 0.01 & 0.03 & 0.04 & 0.05 & 0.02 & 0.02 & 0.01 \\
\hline
\end{tabular}




$\begin{array}{cccccccccccccccccccccccc}\text { Latvia } & -0.10 & 0.05 & 0.16 & 0.25 & 0.27 & 0.31 & 0.37 & 0.37 & 0.32 & 0.25 & 0.24 & 0.22 & 0.24 & 0.31 & 0.42 & 0.46 & 0.41 & 0.42 & 0.42 \\ \text { Lithuania } & -0.83 & -0.33 & -0.12 & 0.05 & 0.09 & 0.12 & 0.21 & 0.23 & 0.25 & 0.25 & 0.23 & 0.21 & 0.21 & 0.24 & 0.30 & 0.36 & 0.33 & 0.34 & 0.33 \\ \text { Malta } & -0.16 & -0.15 & -0.14 & -0.11 & -0.08 & -0.09 & 0.04 & 0.05 & 0.07 & 0.09 & 0.12 & 0.11 & 0.13 & 0.14 & 0.18 & 0.18 & 0.14 & 0.14 & 0.13 \\ \text { Netherlands } & -0.04 & 0.74 & 0.58 & 0.45 & 0.38 & 0.35 & 0.33 & 0.47 & 0.72 & 1.09 & 1.40 & 1.57 & 1.55 & 1.40 & 1.34 & 1.34 & 1.30 & 1.26 & 1.16 \\ \text { Poland } & -0.34 & 0.00 & 0.07 & 0.09 & 0.13 & 0.09 & 0.19 & 0.31 & 0.26 & 0.13 & 0.11 & 0.22 & 0.23 & 0.26 & 0.34 & 0.17 & 0.23 & 0.21 & 0.19 \\ \text { Portugal } & -0.08 & 0.06 & 0.06 & 0.02 & 0.02 & 0.01 & -0.01 & 0.01 & 0.03 & 0.08 & 0.09 & 0.09 & 0.09 & 0.10 & 0.11 & 0.10 & 0.07 & 0.09 & 0.07 \\ \text { Romania } & -0.44 & -0.47 & -0.21 & -0.03 & 0.22 & 0.08 & 0.19 & 0.20 & 0.18 & 0.13 & 0.14 & 0.29 & 0.35 & 0.43 & 0.37 & 0.29 & 0.31 & 0.35 & 0.29 \\ \text { Slovakia } & -0.25 & -0.21 & -0.20 & -0.15 & -0.14 & -0.17 & -0.07 & -0.06 & -0.04 & 0.07 & 0.16 & 0.18 & 0.23 & 0.32 & 0.40 & 0.46 & 0.42 & 0.43 & 0.44 \\ \text { Slovenia } & 0.03 & 0.12 & 0.07 & 0.07 & 0.10 & 0.09 & 0.07 & 0.06 & 0.08 & 0.10 & 0.09 & 0.08 & 0.07 & 0.08 & 0.10 & 0.12 & 0.11 & 0.11 & 0.11 \\ \text { Spain } & -0.02 & 0.00 & 0.02 & -0.03 & -0.03 & -0.04 & -0.07 & -0.06 & -0.04 & 0.01 & 0.02 & 0.03 & 0.04 & 0.06 & 0.09 & 0.09 & 0.07 & 0.07 & 0.06 \\ \text { Sweden } & 0.05 & 0.05 & 0.13 & 0.08 & 0.06 & 0.03 & 0.01 & -0.07 & -0.05 & 0.02 & 0.03 & -0.01 & -0.01 & 0.00 & -0.02 & -0.10 & -0.03 & 0.01 & 0.01 \\ \text { UK } & -0.11 & -0.15 & -0.13 & 0.01 & 0.05 & 0.04 & 0.05 & 0.02 & 0.02 & -0.03 & 0.00 & -0.02 & -0.01 & 0.01 & -0.12 & -0.23 & -0.21 & -0.20 & -0.16\end{array}$


Fig. 1. REER misalignments for core countries

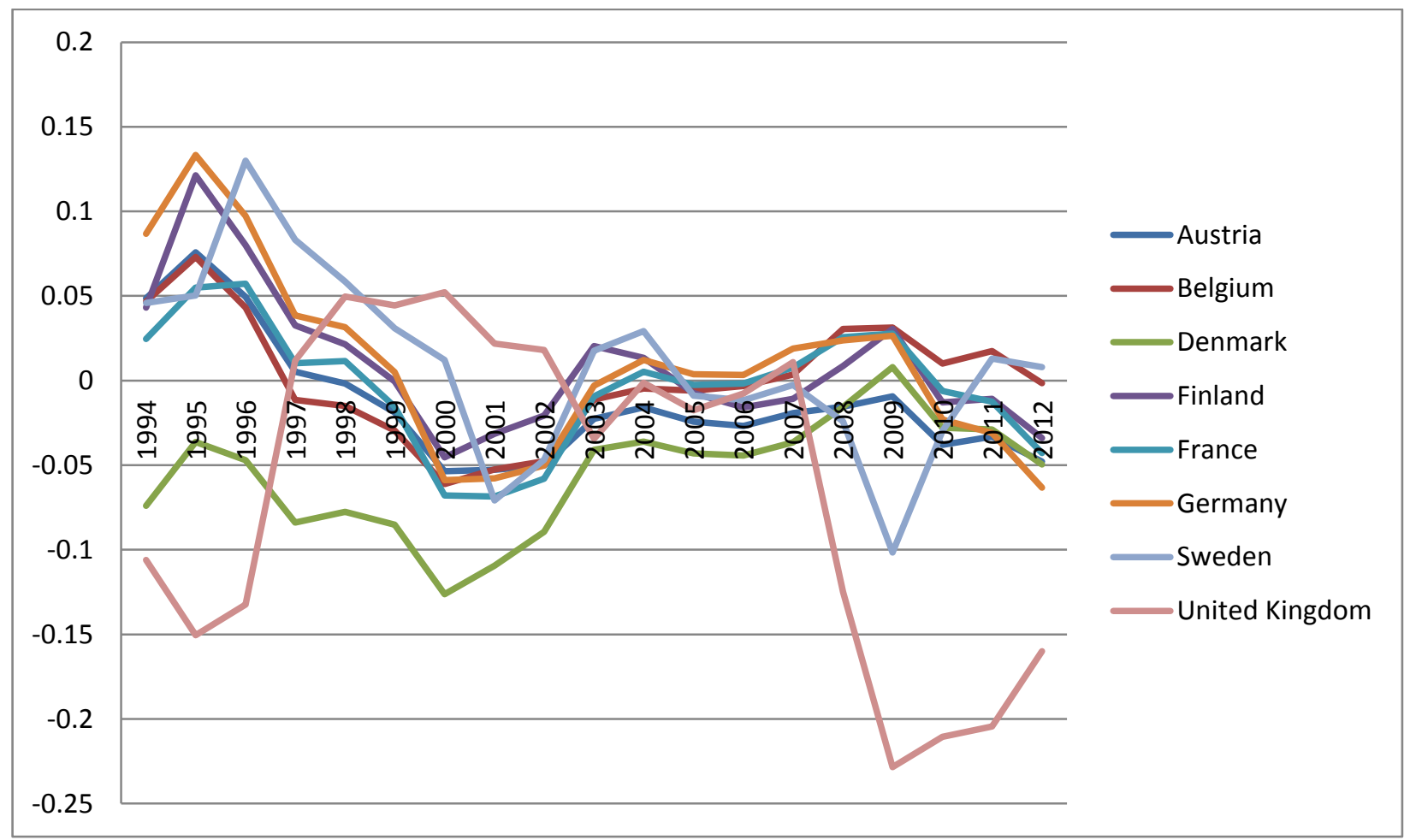

Note: the Netherlands is not included for convenience, as it is an outlier.

Fig. 2. REER misalignments for periphery countries

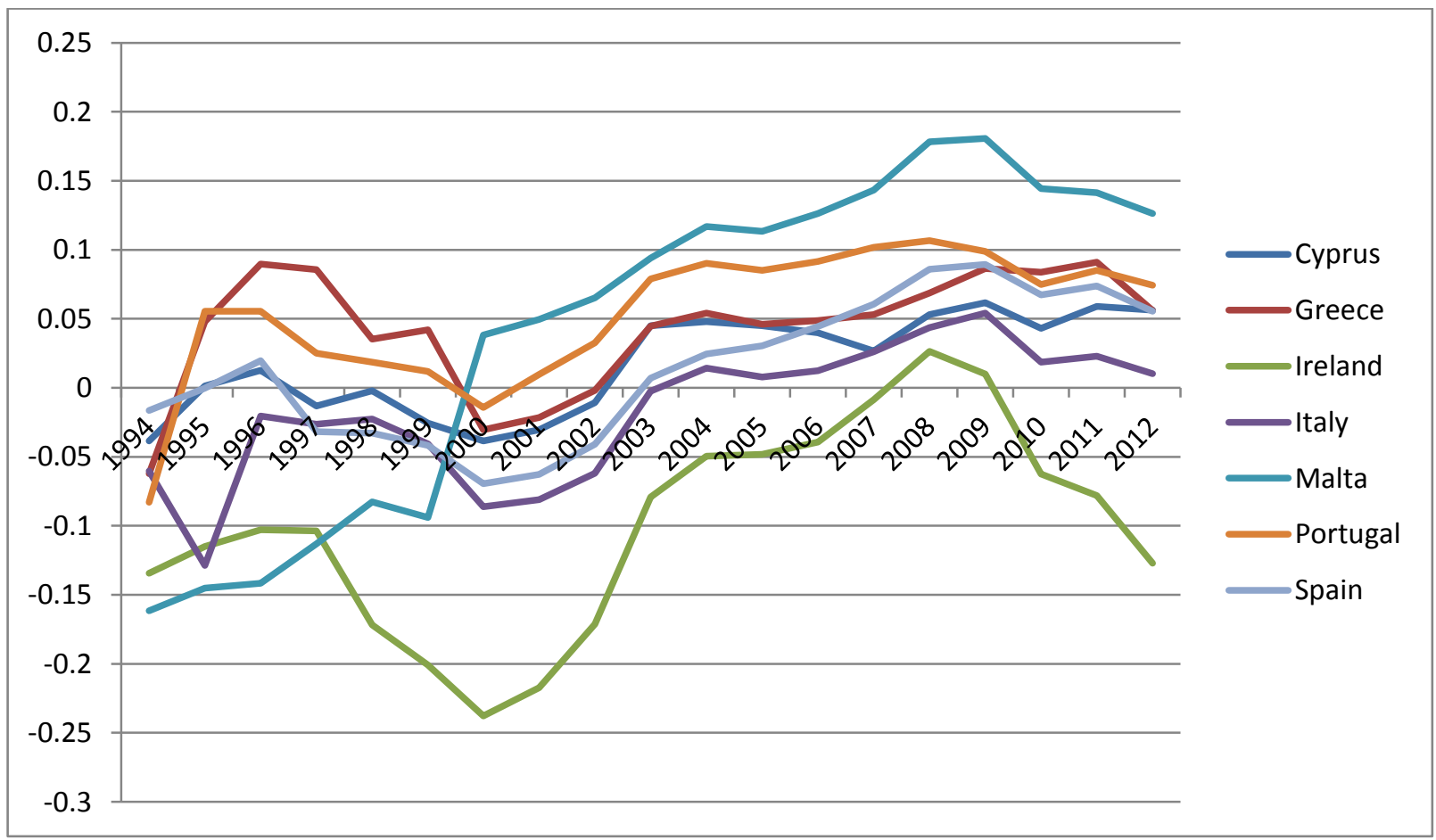


Fig. 3. REER misalignments for CEECs

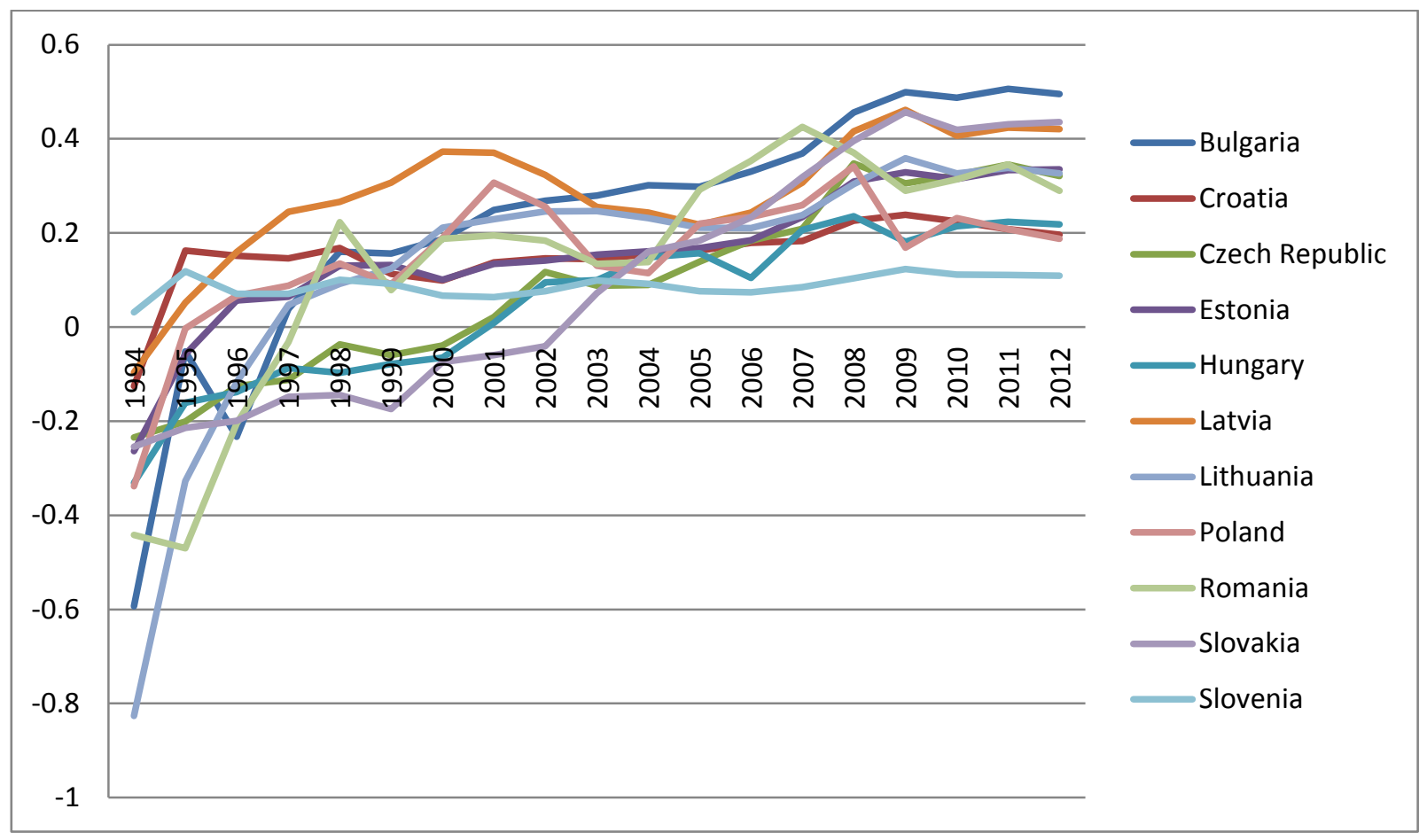


Table 8. PECM results for growth with REER misalignments

Dependent variable: (first difference) real GDP growth

\begin{tabular}{|c|c|c|c|c|}
\hline VARIABLES & $\begin{array}{l}\text { (1) } \\
\text { LR }\end{array}$ & $\begin{array}{l}\text { (2) } \\
\text { SR }\end{array}$ & $\begin{array}{l}\text { (3) } \\
\text { LR }\end{array}$ & $\begin{array}{l}\text { (4) } \\
\text { SR }\end{array}$ \\
\hline \multicolumn{5}{|l|}{ SHORT RUN } \\
\hline D.reer_mis & & $\begin{array}{c}1.535 \\
(6.159)\end{array}$ & & $\begin{array}{c}0.228 \\
(8.903)\end{array}$ \\
\hline D.gov & & $\begin{array}{c}-1.071 * * * \\
(0.269)\end{array}$ & & $\begin{array}{c}-1.108 * * * \\
(0.316)\end{array}$ \\
\hline D.under & & & & $\begin{array}{c}3.097 * \\
(1.762)\end{array}$ \\
\hline Constant & & $\begin{array}{c}16.52 * * * \\
(4.496)\end{array}$ & & $\begin{array}{c}23.50 * * * \\
(3.638)\end{array}$ \\
\hline
\end{tabular}

\section{LONG RUN}

$\begin{array}{lcc}\text { reer_mis } & -17.34 * * * & -17.30 * * \\ & (5.489) & (7.825) \\ \text { gov } & -0.753 * * * & -0.891 * * * \\ & (0.270) & (0.245) \\ \text { under } & & 2.251 \\ & & (4.918)\end{array}$

\begin{tabular}{lllll}
\hline Observations & 484 & 484 & 484 & 484 \\
\hline
\end{tabular}

Standard errors in parentheses $* * * \mathrm{p}<0.01, * * \mathrm{p}<0.05, * \mathrm{p}<0.1$ 
Table 9: PECM results for growth with REER and NEER volatilities

Dependent variable: (first difference) real GDP growth

\begin{tabular}{lllllllll}
\hline & $(1)$ & $(2)$ & $(3)$ & $(4)$ & $(5)$ & $(6)$ & $(7)$ & $(8)$ \\
VARIABLES & LR & SR & LR & SR & LR & SR & LR & SR \\
\hline
\end{tabular}

SHORT RUN

$\begin{array}{lcccc}\text { D.reer_vol } & -11.46^{*} & -9.663 & & \\ & (6.883) & (8.410) & -7.712 & -5.328 \\ \text { D.neer_vol } & & & (6.564) & (8.330) \\ & & & -1.276 * * * & -1.744 * * * \\ \text { D.gov } & -1.243^{* * *} & -1.588^{* * *} & (0.283) & (0.300) \\ & (0.254) & (0.280) & & -2.573 \\ \text { D.under } & & -3.336 & & (3.435) \\ & & (2.809) & 8.216 & 3.980 \\ \text { Constant } & 7.382 & 6.087 & (5.653) & (5.862)\end{array}$

\section{LONG RUN}

$\begin{array}{lcccc}\text { reer_vol } & 53.93 & 80.17 & & \\ & (36.49) & (74.82) & 10.74 & -2.152 \\ \text { neer_vol } & & & (11.08) & (23.24) \\ & & & -0.270 & 0.500 \\ \text { gov } & -0.312 & -0.148 & (0.349) & (0.628) \\ & (0.404) & (0.407) & & 9.203 \\ \text { under } & & 7.087 & & (5.987)\end{array}$

\begin{tabular}{lllllllll}
\hline Observations & 484 & 484 & 484 & 484 & 484 & 484 & 484 & 484 \\
\hline
\end{tabular}

Standard errors in parentheses

$* * * \mathrm{p}<0.01, * * \mathrm{p}<0.05, * \mathrm{p}<0.1$ 
Table 10. PECM with REER misalignments and with corrections for CSD (spillovers and common factors)

Dependent variable: (first difference) real GDP growth

\begin{tabular}{|c|c|c|c|c|}
\hline & (1) & (2) & (3) & (4) \\
\hline VARIABLES & LR & SR & LR & SR \\
\hline \multicolumn{5}{|l|}{ SHORT RUN } \\
\hline D.reer_mis & & 2.034 & & 3.116 \\
\hline D.gov & & $\begin{array}{l}-0.189 \\
(0.442)\end{array}$ & & $\begin{array}{l}-0.333 \\
(0.515)\end{array}$ \\
\hline D.fgdpg & & $\begin{array}{c}-0.201 * * \\
(0.0795)\end{array}$ & & $\begin{array}{c}-0.274 * * \\
(0.119)\end{array}$ \\
\hline D.wgdp & & $\begin{array}{l}0.135 * * \\
(0.0657)\end{array}$ & & $\begin{array}{l}0.171 * * \\
(0.0829)\end{array}$ \\
\hline D.under & & & & $\begin{array}{c}3.037 \\
(2.021)\end{array}$ \\
\hline Constant & & $\begin{array}{c}6.204 \\
(5.393)\end{array}$ & & $\begin{array}{c}9.120 \\
(6.486)\end{array}$ \\
\hline
\end{tabular}

\section{LONG RUN}

$\begin{array}{lcc}\text { reer_mis } & -7.156^{49} & -10.65 * \\ & (5.314) & (6.239) \\ \text { gov } & 0.0474 & 1.089 \\ & (0.272) & (1.096) \\ \text { fgdpg } & 0.880 * * * & 0.899 * * * \\ & (0.162) & (0.249) \\ \text { wgdp } & -0.0405 & -0.0410 \\ & (0.0279) & (0.0275) \\ \text { under } & & 4.691 \\ & & (5.866)\end{array}$

Observations 484

Standard errors in parentheses

$* * * \mathrm{p}<0.01, * * \mathrm{p}<0.05, * \mathrm{p}<0.1$

${ }^{49}$ The p-value in this case is 0.178 . Hence, misalignments are significant at $20 \%$ level. 
Table 11. PECM with volatilities and with corrections for CSD (spillovers and common factors)

Dependent variable: (first difference) real GDP growth

\begin{tabular}{|c|c|c|c|c|c|c|c|c|}
\hline & (1) & (2) & (3) & (4) & (5) & (6) & (7) & (8) \\
\hline VARIABLES & LR & SR & LR & SR & LR & SR & LR & SR \\
\hline \multicolumn{9}{|l|}{ SHORT RUN } \\
\hline D.reer_vol & & $\begin{array}{l}-1.331 \\
(7.909)\end{array}$ & & $\begin{array}{c}3.937 \\
(7.525)\end{array}$ & & & & \\
\hline D.neer_vol & & & & & & $\begin{array}{l}-2.337 \\
(7.471)\end{array}$ & & $\begin{array}{c}1.778 \\
(7.337)\end{array}$ \\
\hline D.gov & & $\begin{array}{l}-0.479 \\
(0.418)\end{array}$ & & $\begin{array}{l}-0.492 \\
(0.466)\end{array}$ & & $\begin{array}{l}-0.304 \\
(0.468)\end{array}$ & & $\begin{array}{l}-0.251 \\
(0.491)\end{array}$ \\
\hline D.fgdpg & & $\begin{array}{c}-0.116 \\
(0.0910)\end{array}$ & & $\begin{array}{c}-0.190 * * \\
(0.0788)\end{array}$ & & $\begin{array}{l}-0.147^{*} \\
(0.0876)\end{array}$ & & $\begin{array}{c}-0.189 * * \\
(0.0901)\end{array}$ \\
\hline D.wgdp & & $\begin{array}{c}0.185 * * * \\
(0.0664)\end{array}$ & & $\begin{array}{l}0.157 * * \\
(0.0687)\end{array}$ & & $\begin{array}{l}0.164 * * \\
(0.0640)\end{array}$ & & $\begin{array}{c}0.225 * * * \\
(0.0690)\end{array}$ \\
\hline D.under & & & & $\begin{array}{l}-0.770 \\
(1.351)\end{array}$ & & & & $\begin{array}{c}-0.00631 \\
(2.120)\end{array}$ \\
\hline Constant & & $\begin{array}{c}2.720 \\
(7.673)\end{array}$ & & $\begin{array}{c}4.881 \\
(7.443)\end{array}$ & & $\begin{array}{c}4.240 \\
(7.120)\end{array}$ & & $\begin{array}{c}10.36 \\
(6.434)\end{array}$ \\
\hline
\end{tabular}

\section{LONG RUN}

$\begin{array}{lcccc}\text { reer_vol } & 5.997 & -13.12 & & \\ & (23.45) & (19.37) & 4.461 & -5.228 \\ \text { neer_vol } & & & (12.61) & (16.52) \\ & & & -0.0760 & 0.542 \\ \text { gov } & 0.121 & 0.753 & (0.337) & (0.807) \\ & (0.391) & (0.550) & 0.781 * * * & 0.662 * * * \\ \text { fgdpg } & 0.695 * * * & 0.970 * * * & (0.168) & (0.187) \\ & (0.158) & (0.227) & -0.0504 * * * & -0.0784 * * * \\ \text { wgdp } & -0.0657 * * * & -0.0693 * * * & (0.0170) & (0.0228) \\ & (0.0198) & (0.0256) & & 8.522 \\ \text { under } & & 6.165 & & (6.203)\end{array}$


Table 12. dynamic factor model with REER misalignments - AMG

\begin{tabular}{lcc} 
dependent variable: real GDP growth & \\
\hline & $(1)$ & $(2)$ \\
VARIABLES & gdpgr & gdpgr \\
\hline & & \\
L.gdpgr & $-0.0952^{*}$ & $-0.103^{*}$ \\
& $(0.0564)$ & $(0.0601)$ \\
reer_mis & $-9.176^{* * *}$ & $-10.51^{* *}$ \\
& $(3.533)$ & $(4.536)$ \\
gov & -0.0617 & -0.259 \\
& $(0.203)$ & $(0.165)$ \\
under & & 0.215 \\
& & $(0.684)$ \\
Constant & 1.946 & $10.45^{* * *}$ \\
& $(4.175)$ & $(3.639)$ \\
& & \\
Common dynamic process & $0.856^{* * *}$ & $0.812^{* * *}$ \\
& $(0.0934)$ & $(0.0982)$ \\
& & \\
\hline Observations & 484 & 484 \\
Number of co & 27 & 27 \\
\hline Standard errors in parentheses & \\
$* * *$ p $<0.01, * * \mathrm{p}<0.05, * \mathrm{p}<0.1$ &
\end{tabular}


Table 13. dynamic factor model with REER and NEER volatilities -AMG

\begin{tabular}{|c|c|c|c|c|}
\hline VARIABLES & $\begin{array}{c}(1) \\
\text { gdpgr }\end{array}$ & $\begin{array}{c}(2) \\
\text { gdpgr }\end{array}$ & $\begin{array}{c}\text { (3) } \\
\text { gdpgr }\end{array}$ & $\begin{array}{c}\text { (4) } \\
\text { gdpgr }\end{array}$ \\
\hline L.gdpgr & $\begin{array}{l}-0.0767 \\
(0.0557)\end{array}$ & $\begin{array}{l}-0.0758 \\
(0.0599)\end{array}$ & $\begin{array}{l}-0.0706 \\
(0.0561)\end{array}$ & $\begin{array}{l}-0.0679 \\
(0.0595)\end{array}$ \\
\hline reer_vol & $\begin{array}{c}-8.058^{*} \\
(4.274)\end{array}$ & $\begin{array}{l}-6.379 \\
(5.181)\end{array}$ & & \\
\hline neer_vol & & & $\begin{array}{l}-1.784 \\
(5.340)\end{array}$ & $\begin{array}{l}-1.664 \\
(5.431)\end{array}$ \\
\hline gov & $\begin{array}{l}-0.189 \\
(0.212)\end{array}$ & $\begin{array}{c}-0.332 * * \\
(0.145)\end{array}$ & $\begin{array}{l}-0.183 \\
(0.212)\end{array}$ & $\begin{array}{c}-0.308^{* *} \\
(0.141)\end{array}$ \\
\hline under & & $\begin{array}{c}1.063 \\
(0.704)\end{array}$ & & $\begin{array}{c}0.870 \\
(0.682)\end{array}$ \\
\hline Constant & $\begin{array}{c}4.121 \\
(4.155)\end{array}$ & $\begin{array}{c}11.75^{* * * *} \\
(3.165)\end{array}$ & $\begin{array}{c}3.713 \\
(4.079)\end{array}$ & $\begin{array}{c}11.06 * * * \\
(3.099)\end{array}$ \\
\hline Common dynamic process & $\begin{array}{c}0.840 * * * \\
(0.0936)\end{array}$ & $\begin{array}{c}0.816 * * * \\
(0.102)\end{array}$ & $\begin{array}{c}0.832 * * * \\
(0.0906)\end{array}$ & $\begin{array}{c}0.811^{* * *} \\
(0.0977)\end{array}$ \\
\hline Observations & 484 & 484 & 484 & 484 \\
\hline Number of co & 27 & 27 & 27 & 27 \\
\hline
\end{tabular}

Standard errors in parentheses

$* * * \mathrm{p}<0.01, * * \mathrm{p}<0.05, * \mathrm{p}<0.1$ 
Table 14. dynamic factor model with REER misalignment and volatility - CCE-GMM (IV)

\begin{tabular}{|c|c|c|c|c|}
\hline VARIABLES & $\begin{array}{c}(1) \\
\text { gdpgr }\end{array}$ & $\begin{array}{c}(2) \\
\text { gdpgr }\end{array}$ & $\begin{array}{c}(3) \\
\text { gdpgr }\end{array}$ & $\begin{array}{c}\text { (4) } \\
\text { gdpgr }\end{array}$ \\
\hline L.gdpgr & $\begin{array}{l}0.354^{*} \\
(0.206)\end{array}$ & $\begin{array}{c}10.02 \\
(26.82)\end{array}$ & $\begin{array}{c}0.358 * * \\
(0.161)\end{array}$ & $\begin{array}{l}-8.267 \\
(17.82)\end{array}$ \\
\hline reer_mis & $\begin{array}{c}6.106 \\
(12.22)\end{array}$ & $\begin{array}{c}0.379 \\
(1.006)\end{array}$ & & \\
\hline reer_vol & & & $\begin{array}{c}11.32 \\
(20.02)\end{array}$ & $\begin{array}{l}-1.065 \\
(0.778)\end{array}$ \\
\hline gov & $\begin{array}{c}0.611 \\
(0.621)\end{array}$ & $\begin{array}{l}-6.312 \\
(6.652)\end{array}$ & $\begin{array}{l}-0.396 \\
(0.542)\end{array}$ & $\begin{array}{c}2.093 \\
(1.328)\end{array}$ \\
\hline under & & $\begin{array}{c}0.193 \\
(0.198)\end{array}$ & & $\begin{array}{l}0.0333 \\
(0.142)\end{array}$ \\
\hline gdpgr_csa & $\begin{array}{c}1.285^{* * *} \\
(0.278)\end{array}$ & $\begin{array}{c}1.531 * * \\
(0.766)\end{array}$ & $\begin{array}{c}0.936 * * * \\
(0.121)\end{array}$ & $\begin{array}{c}0.784 * * * \\
(0.190)\end{array}$ \\
\hline under_csa & & $\begin{array}{l}-0.838 \\
(5.388)\end{array}$ & & $\begin{array}{l}-2.412 \\
(2.597)\end{array}$ \\
\hline reer_mis_csa & $\begin{array}{l}-20.62 \\
(17.24)\end{array}$ & $\begin{array}{l}-11.52 \\
(29.05)\end{array}$ & & \\
\hline reer_vol_csa & & & $\begin{array}{l}-61.54 \\
(45.70)\end{array}$ & $\begin{array}{c}10.67 \\
(31.79)\end{array}$ \\
\hline gov_csa & $\begin{array}{c}2.434 \\
(1.959)\end{array}$ & $\begin{array}{c}0.852 \\
(2.055)\end{array}$ & $\begin{array}{c}0.552 \\
(0.453)\end{array}$ & $\begin{array}{c}0.371 \\
(0.556)\end{array}$ \\
\hline constant & $\begin{array}{c}-59.72 * \\
(35.76)\end{array}$ & $\begin{array}{l}-23.61 \\
(36.48)\end{array}$ & $\begin{array}{l}-6.618 \\
(13.24)\end{array}$ & $\begin{array}{c}14.96 \\
(20.92)\end{array}$ \\
\hline Observations & 457 & 457 & 457 & 457 \\
\hline Number of co & 27 & 27 & 27 & 27 \\
\hline
\end{tabular}

Note: The suffix _csa is used to denote the cross section average of the preceding variables and can be seen as other ways to make explicit the unobserved common factors. 
Table 15. dynamic factor model with BEER-based and FEER-based misalignments for CEECs

\begin{tabular}{|c|c|c|c|c|}
\hline VARIABLES & $\begin{array}{c}(1) \\
\text { gdpgr }\end{array}$ & $\begin{array}{c}(2) \\
\text { gdpgr }\end{array}$ & $\begin{array}{c}(3) \\
\text { gdpgr }\end{array}$ & $\begin{array}{c}(4) \\
\text { gdpgr }\end{array}$ \\
\hline L.gdpgr & $\begin{array}{c}0.0262 \\
(0.0811)\end{array}$ & $\begin{array}{c}0.0253 \\
(0.0825)\end{array}$ & $\begin{array}{c}-0.0352 \\
(0.0586)\end{array}$ & $\begin{array}{c}-0.0284 \\
(0.0539)\end{array}$ \\
\hline reer_mis & $\begin{array}{c}-22.69 * * * \\
(5.275)\end{array}$ & $\begin{array}{c}-23.33 * * * \\
(5.334)\end{array}$ & & \\
\hline feer_mis & & & $\begin{array}{c}7.928 * * \\
(3.253)\end{array}$ & $\begin{array}{c}5.934 \\
(5.161)\end{array}$ \\
\hline gov & $\begin{array}{c}-0.0391 \\
(0.353)\end{array}$ & $\begin{array}{c}-0.0305 \\
(0.368)\end{array}$ & $\begin{array}{c}-0.511^{* *} \\
(0.203)\end{array}$ & $\begin{array}{c}-0.321^{*} \\
(0.190)\end{array}$ \\
\hline under & & $\begin{array}{l}-0.0996 \\
(0.0996)\end{array}$ & & \\
\hline under_feer & & & & $\begin{array}{l}-0.114 \\
(0.526)\end{array}$ \\
\hline Constant & $\begin{array}{c}8.072 \\
(7.245)\end{array}$ & $\begin{array}{c}8.223 \\
(7.574)\end{array}$ & $\begin{array}{c}13.05 * * * \\
(4.121)\end{array}$ & $\begin{array}{c}9.470 * * \\
(3.802)\end{array}$ \\
\hline Common dynamic process & $\begin{array}{c}0.970 * * * \\
(0.109)\end{array}$ & $\begin{array}{c}0.968 * * * \\
(0.108)\end{array}$ & $\begin{array}{c}0.954 * * * \\
(0.145)\end{array}$ & $\begin{array}{c}0.994 * * * \\
(0.147)\end{array}$ \\
\hline Observations & 132 & 132 & 132 & 132 \\
\hline Number of co & 11 & 11 & 11 & 11 \\
\hline
\end{tabular}

Standard errors in parentheses

$* * * \mathrm{p}<0.01, * * \mathrm{p}<0.05, * \mathrm{p}<0.1$ 
Table 16. PECM with NEER and CPI volatilities

dependent variable (first difference) GDP growth

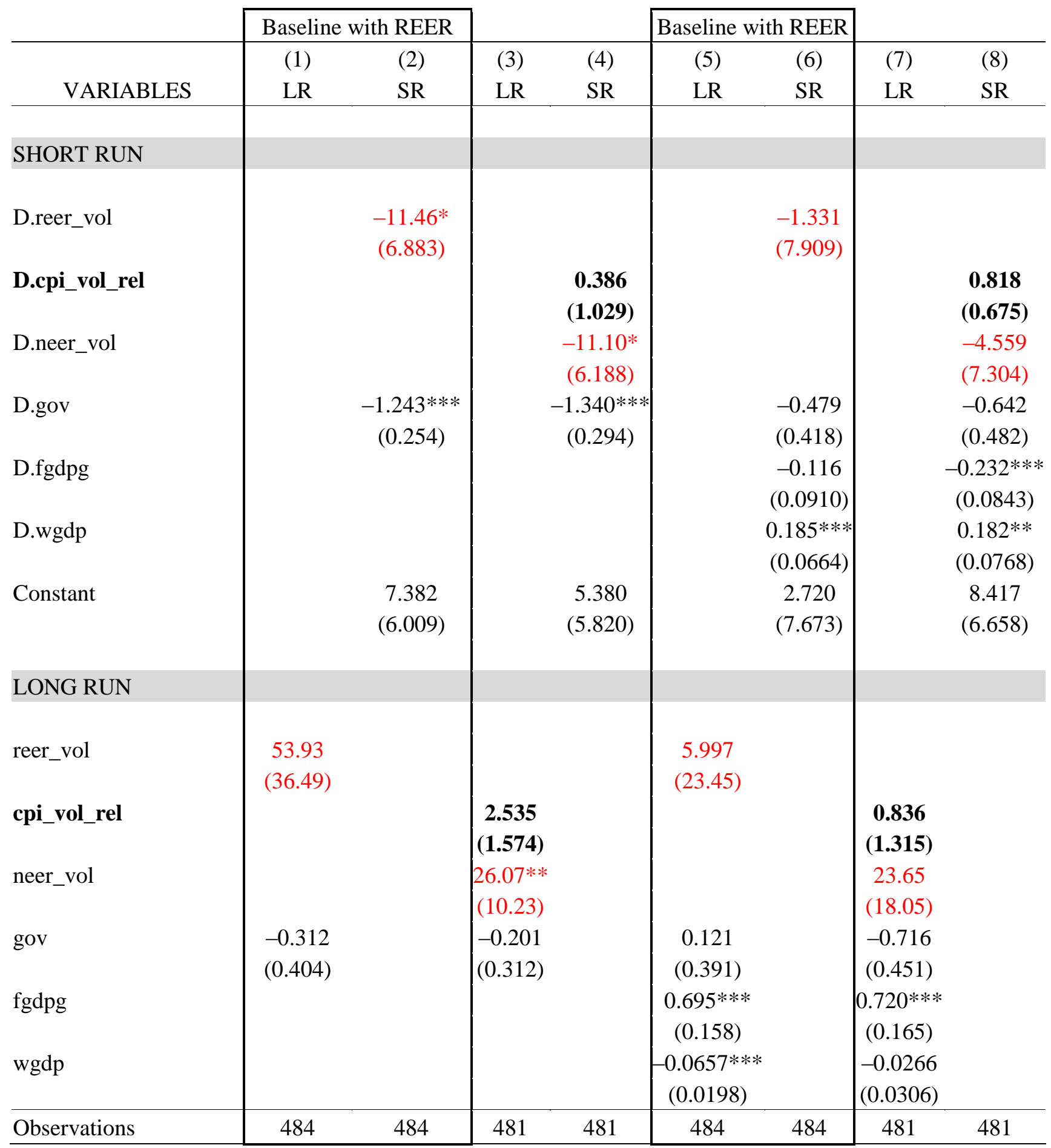

Note: cpi_vol_rel is the CPI volatility in relative terms. 


\section{References}

Aguirre, A., Calderon, C. (2005). "Real Exchange Rate Misalignments and Economic Performance”, Central Bank of Chile, Economic Research Division.

Amuedo-Dorantes, C., Pozo, S. (2004). "Workers' Remittances and the Real Exchange Rate: a Paradox of Gifts", World Development 32, pp. 1407-1417.

Arpaia, A., Turrini, A. (2008). "Government expenditure and economic growth in the EU: long-run tendencies and short-term adjustment", European Economy - Economic Papers 300, Directorate General Economic and Financial Affairs (DG ECFIN), European Commission.

Auerbach, A. J., Gorodnichenko Y. (2012). "Measuring the Output Responses to Fiscal Policy", American Economic Journal: Economic Policy 4(2), pp. 1-27.

Bagella, M., Becchetti, L., Hasan, I. (2006). "Real effective exchange rate volatility and growth: A framework to measure advantages of flexibility vs. costs of volatility," Journal of Banking \& Finance 30(4), April, Elsevier, pp. 1149-1169.

Barro, R. J. (1991). "Economic growth in a cross section of countries," Quarterly Journal of Economics 106(2), pp. 407-443.

Bems, R. and Johnson, R.C. (2012). "Value-Added Exchange Rates", NBER Working Papers 18498, National Bureau of Economic Research, Inc.

Bems R., Johnson, R.C. (2015). "Demand for Value Added and Value-Added Exchange Rates", NBER Working Papers 21070, National Bureau of Economic Research, Inc.

Bénassy-Quéré, A., Béreau, S., Mignon, V. (2009). "Robust estimations of equilibrium exchange rates within the G20: A panel BEER approach". Scottish Journal of Political Economy 56(5), pp. 608-633.

Bénassy-Quéré, A., Béreau, S., Mignon, V. (2010). "On the complementarity of equilibrium exchange-rate approaches", Review of International Economics 18(4), pp. 618-632.

Berg, A., Miao, Y. (2010). "The Real Exchange Rate and Growth Revisited: The Washington Consensus Strikes Back?”, IMF Working Paper 10/58.

Blanchard, O., Perotti, R. (2002). "An Empirical Characterization of the Dynamic Effects of Changes in Government Spending and Taxes on Output", Quarterly Journal of Economics 117(4), pp. 1329-68

Boar, C. G. (2010). "Exchange Rate Volatility and Growth in Emerging Europe", The Review of Finance and Banking, 2(2), pp. 103-120.

Brahmbhatt, M., Canuto, O., Vostroknutova, E. (2010). "Dealing with Dutch Disease", World Bank Economic Premise, Issue 16, pp. 1-7.

Bussière, M., Lopez, C., Tille, C. (2014). "Do Real Exchange Rate Appreciations Matter for Growth?", IHEID Working Papers 06-2014, Economics Section, The Graduate Institute of International Studies.

Clancy, D. \& Jacquinot, P., Lozej, M. (2014). "The effects of government spending in a small open economy within a monetary union", Working Paper Series 1727, European Central Bank.

Clark, P. B., MacDonald, R. (1999). "Exchange Rates and Economic Fundamentals: a Methodological Comparison of BEERS and FEERS", In Equilibrium Real Exchange Rates, ed. by R. MacDonald and J.L. Stein (Massachusetts: Kluwer Academic Publishers), pp. 209-40.

Coenen, G., Erceg, C., Freedman, C., Furceri, D., Kumhof, M., Lalonde, R., Laxton, D., Lindé, J., Mourougane, A., Muir, D., Mursula, S., de Resende, C.,Roberts, J., Roeger, W., Snudden, S., Trabandt, M. and in't Veld, J. (2012). "Effects of fiscal stimulus in structural models", American Economic Journal: Macroeconomics 4(1), pp. 22-68.

Combes, J. L., Kinda, T., Plane, P. (2012). "Capital flows, exchange rate flexibility, and the real exchange rate", Journal of Macroeconomics 34(4), pp. 1034-1043.

Comunale, M. (2015a). "Long-run determinants and misalignments of the real effective exchange rate in the EU”, Bank of Lithuania Working Paper Series (2015, No 18)

Comunale, M. (2015b). "Current Account and REER misalignments in Central Eastern EU Countries: an update using the Macroeconomic Balance approach", BOFIT Bank of Finland, Discussion Paper Series No 28/2015.

Corden, W. M. (1994). "Economic Policy, Exchange Rates, and the International System", University of Chicago Press. 
Corsetti G., Meier A., Müller G. J. (2012). "Fiscal Stimulus with Spending Reversals," The Review of Economics and Statistics, MIT Press, 94(4), November, pp. 878-895.

Cottani, J. A., Cavallo, D. F., Khan, M. S. (1990). "Real Exchange Rate Behavior and Economic Performance in LDCs", Economic Development and Cultural Change, 39(1), pp. 61-76.

Dollar, D. (1992). "Outward-Oriented Developing Economies Really Do Grow More Rapidly: Evidence from 95 LDCs, 1976-1985", Economic Development and Cultural Change 40(3), April, pp. 523-544.

Dooley, M., D. Folkerts-Landau, Garber, P. (2003). “An Essay on the Revived Bretton Woods System”, NBER Working Paper No 9971.

Eberhardt, M., Teal, F. (2010). "Productivity Analysis in Global Manufacturing Production", Economics Series Working Papers 515, University of Oxford, Department of Economics.

Eberhardt, M. (2012). "Estimating panel time-series models with heterogeneous slopes", Stata Journal 12(1), pp. 61-71.

Eichengreen, B. (2008). "The Real Exchange Rate and Economic Growth", Commission on Growth and Development Working Paper, No 4, The World Bank, 2008.

Gala, P., Lucinda, C.R. (2006). "Exchange Rate Misalignment and Growth: Old and New Econometric Evidence", Revista Economia, pp. 165-87.

Galstyan, V., Lane, P. R. (2009). "Fiscal policy and international competitiveness", Economic and Social Review 40(3), pp. 299-315.

Gonzalo, J., Granger, C. W. J, (1995). "Estimation of Common Long-Memory Components in Cointegrated Systems", Journal of Business \& Economic Statistics, American Statistical Association, Vol 13(1), January, pp. 27-35.

Gylfason, T., Herbertson, T. T., Zoega, G. (1999). “A Mixed Blessing: Natural Resources and Economic Growth," Macroeconomic Dynamics, Vol 3, 204-25.

Hall, R.E. (2009). "By how much does GDP rise if the government buys more output?", Brookings Papers on Economic Activity 2, 2009, pp. 183-231.

Hau, H. (2002). "Real exchange rate volatility and economic openness: theory and evidence", Journal of money, Credit and Banking, pp. 611-630.

Holland, M., Vieira, F. V., Gomes, C., Bottecchia, S.L.C. (2011). "Growth and exchange rate volatility: a panel data analysis", 39o Encontro Nacional de Economia-Anpec, Foz do Iguaçú. Anais do 39o Encontro Nacional de Economia-Anpec.

Im, K. S., Pesaran, M. H., Shin, Y. (2003). "Testing for unit roots in heterogeneous panels", Journal of econometrics $115(1)$, pp. 53-74.

International Monetary Fund (2005). "The Macroeconomics of Managing Increased Aid Inflows: Experiences of Low-Income Countries and Policy Implications", Washington D.C.

Leeper, E. M., Walker, T. B., \& Yang, S-C. S. (2010). "Government investment and fiscal stimulus", Journal of Monetary Economics, Vol 57, pp. 1000-1012.

Lane, P. R., Milesi-Ferretti, G. M. (2002). "External wealth, the trade balance, and the real exchange rate", European Economic Review 46(6), pp. 1049-1071.

Lane, P. R., Milesi-Ferretti, G. M. (2004). "The transfer problem revisited: Net foreign assets and real exchange rates", Review of Economics and Statistics, 86(4), pp. 841-857.

Lartey, E., Mandelman, F., Acosta, P. (2008). "Remittances, Exchange Rate Regimes and the Dutch Disease: A Panel Data Analysis", Federal Reserve Bank of Atlanta Working Paper 2008-12.

Maeso-Fernandez, F., Osbat, C., Schnatz, B. (2002). "Determinants of the euro real effective exchange rate: A BEER/PEER approach", Australian Economic Papers 41(4), pp. 437-461.

Magud, N. E., Sosa, S. (2010). "When and Why Worry About Real Exchange Rate Appreciation? The Missing Link Between Dutch Disease and Growth", IMF Working Papers, pp. 1-32.

Milesi-Ferretti, G M and Tille, C (2011), "The Great Retrenchment: International Capital Flows During the Global Financial Crisis", Economic Policy 66, 285-342.

Mussa, M. (1986). "Nominal Exchange Rate Regimes and the Behavior of the Real Exchange Rate", Carnegie Rochester Series on Public Policy 25, pp. 117-213.

Neal, T. (2015). "Estimating Heterogeneous Coefficients in Panel Data Models with Endogenous Regressors and Common Factors", Working Paper.

Nickell, S. (1981). "Biases in Dynamic Models with Fixed Effects”, Econometrica 49, 1981, pp. 1417-1426. 
Owoundi F., (2016), "Do exchange rate misalignments really affect economic growth? The case of SubSaharan African countries", International Economics, Volume 145, May 2016, Pages 92-110.

Pedroni, P. (2000). "Fully modified OLS for heterogeneous cointegrated panels", in B.H. Baltagi, eds., "Nonstationary panels, panel cointegration, and dynamic panels", Advances in Econometrics 15, (JAI), pp. 93-130.

Pesaran, M. H. (2004). “General Diagnostic Tests for Cross Section Dependence in Panels”, CESifo Working Paper Series, No 1229, IZA Discussion Paper, No 1240.

Pesaran, M.H. (2006). "Estimation and inference in large heterogeneous panels with a multifactor error structure", Econometrica 74(4), pp. 967-1012.

Pesaran M.H., Tosetti E. (2011). "Large panels with common factors and spatial correlation", Journal of Econometrics 161, pp. 182-202.

Pesaran, M.H. and Chudik, A. (2015). "Common correlated effects estimation of heterogeneous dynamic panel data models with weakly exogenous regressors", Journal of Econometrics, 188(2), pp. 393-420.

Rajan, R., Subramanian, A. (2005). "What Undermines Aid's Impact on Growth?” IMF WP/05/126.

Rajan, R., Subramanian, A. (2009). "Aid, Dutch Disease, and Manufacturing Growth," Center for Global Development Working Paper 196.

Rodrik, D. (2008). "The Real Exchange Rate and Economic Growth", Brookings Papers on Economic Activity, Fall 2008.

Roodman, D. (2006). "How to do xtabond2: an introduction to 'Difference' and 'System' GMM in Stata", Center for Global Development Working Paper No 103.

Sarafidis, V., Wansbeek, T. (2012). "Cross-sectional dependence in panel data analysis", Econometric Reviews, 31(5), pp. 483-531.

Schmitz, M., De Clercq, M., Fidora, M., Lauro, B., Pinheiro, C. (2011). "Revisiting the Effective Exchange Rates of the Euro". ECB Occasional Paper, No 134, June 2012, European Central Bank, pp. 1-35.

Schnatz, B. (2011). "Global imbalances and the pretence of knowing fundamental equilibrium exchange rates", Pacific Economic Review, 16(5), pp. 604-615.

Sokolova M.V. (2015). "Exchange Rates and Economic Growth: Re-Evaluation of Undervaluation", proceedings of the Dynamics, Economic Growth, and International Trade - DEGIT XX in Geneva, mimeo.

Solberger, M. (2011). "Demeaning the data in panel-cointegration models to control for cross-sectional dependencies", Economics Letters, 110(3), pp. 252-254.

Vieira F., MacDonald, R. (2012). "A Panel Data Investigation of Real Exchange Rate Misalignment and Growth", Estudios economicos, 42(3), 2012, pp. 433-456.

Vieira, F. V., Holland, M., da Silva, C. G., Bottecchia, L. C. (2013). "Growth and exchange rate volatility: a panel data analysis", Applied Economics, 45(26), pp. 3733-3741.

Westerlund, J. (2007). "Testing for error correction in panel data", Oxford Bulletin of Economics and Statistics, 69(6), pp. 709-748.

Williamson, J. (1990). "What Washington Means by Policy Reform", in Latin American Adjustment: How Much Has Happened?, John Williamson, ed. Washington, Institute for International Economics. 